\title{
Biology and Pathogenicity of Autonomous Parvoviruses
}

\author{
GüNter SiegL
}

\section{INTRODUCTION}

During the past ten years parvoviruses have attracted considerable interest. This is in part due to their unique molecular organization as well as to the fact that they provide an excellent experimental tool to study the replication of a small, single-stranded viral DNA genome and to probe into the synthesis of eucaryotic cell DNA. On the other hand, parvoviruses were shown to be associated with various economically important diseases of animals. At lease since the very recent world-wide epidemic of canine parvovirus enteritis they are no longer regarded as constituting a mere laboratory problem.

In parallel to this increasing importance of parvoviruses as causative agents of specific diseases, several excellent articles on individual parvoviruses have been published (Toolan, 1972; Siegl, 1976; Porter and Cho, 1980; Porter et al., 1980; Mengeling, 1981). These reviews list the available information on distinct characteristics of the viruses in great detail. The present article, on the contrary, traces the properties in common to the various autonomous parvoviruses. It places emphasis on those characteristics which allow rapid and unambiguous identification of individual members of this genus and attempts to provide a basis for the general understanding of this group of viruses.

GÜNTER SIEGL - Institute for Hygiene and Medical Microbiology, University of Bern, $\mathrm{CH} 3010$ Bern, Switzerland. 


\section{A. History of Isolation}

Isolation of autonomous parvoviruses can be dealt with under two distinct headings, i.e., the isolation by chance and isolation as the result of an intensive search for the causative agent of a specific infectious disease. By far the most parvoviruses have been isolated accidentally. Rat virus (RV), the type species of the genus Parvovirus, owes its discovery to the search for an anticipated papovavirus of rats. In the course of these investigation, Kilham and Olivier (1959) inoculated tumor tissue homogenates from three rats into rat embryonic cell cultures and observed the replication of a small, hemagglutinating virus of outstanding stability. In subsequent years similar viruses were frequently recovered from tissues of tumor-bearing rats as well as from tissue of rats treated with carcinogenic or immunosuppressive chemicals (Zhdanov and Merekalova, 1962; Kilham and Molony, 1964; Spencer, 1967). Thus, X-14 virus was isolated in rat embryonic cell cultures inoculated with mammary tumor homogenates of rats X-irradiated and treated with methyl cholanthrene (Payne et al., 1963). The LS agent was recovered by similar techniques from a rat bearing a chloroleukemic tumor (Lum and Schreiner, 1963), and the "hemorrhagic encephalopathy of rats" (HER) agent was found to be responsible for an acute paralysis of the hind limbs of rats which developed after the animals were treated with high concentrations of cyclophosphamide (El Dadah et al., 1967). All these viruses as well as those recovered by Kilham and Molony (1964), Spencer (1967), and Zhdanov and Merekalova (1962) are serologically closely related.

At about the same time as Kilham and Olivier (1959) isolated RV, Toolan (1960) and Toolan and co-workers (1960) observed the development of a rather complex syndrome after inoculation of fractions or cellfree filtrates of transplantable human tumors into newborn hamsters. These animals developed dwarfism, microcephalic domed head, fragility of bones, and malformation of teeth. The causative virus was identified in samples originating from the human tumor HEp-1. It shared many characteristics with RV, yet proved to be serologically distinct from this virus. Because of its source it was named $\mathrm{H}-1$ virus. Under almost identical experimental conditions $\mathrm{H}-3$ virus was recovered from the human tumor HEp-3 (Dalldorf, 1960) and injection of various tissues of cancer patients (Toolan, 1961a,b) as well as of human embryos and placentas (Toolan et al., 1962) into hamster neonates led to the repeated isolation of $\mathrm{H}-1$ virus and the detection of the serologically related $\mathrm{HT}$ virus. The still scarcely characterized $\mathrm{HB}$ virus also originated from such studies (Toolan, 1964).

A constant and apparently inexhaustable source for the isolation of viruses with the physicochemical characteristics of parvoviruses are primary and permanent cultures of cells from various animals and man. Hallauer and Kronauer (1962) became aware of latent infections of per- 
manent human cell lines with parvoviruses when uninfected cultures subjected to treatment with the alkaline glycine buffer (Hallauer and Kronauer, 1960) yielded a then unidentified hemagglutinating agent. Between 1960 and 1970 a total of 43 strains of permanent human cell lines such as HeLa, KB, HEp-2, FL-Amnion, Lu106 have yielded a total of 38 isolates (Hallauer et al., 1971). The great majority (29) of these isolates, represented by the prototype KBSH virus, proved to be serologically related to porcine parvovirus (PPV). Eight isolates represented by the prototype TVX ( = tumor virus X) and LuIII virus (isolated only once from Lu106 cells) were antigenically unrelated to any other known parvovirus. Circumstantial evidence (Hallauer et al., 1971) and direct isolation (Croghan et al., 1973) support the view that the viruses serologically related to PPV had been transmitted to the cultures by the use of trypsin derived from the pancreas of PPV-infected pigs. The origin of TVX and LuIII-type viruses, on the other hand, is still unknown.

Hallauer et al. (1971) also reported on the isolation of a serologically unique parvovirus (RTV) from a permanent line of rat cells (AT) originally established by P. Tournier. In contrast, the agents isolated by Melnick et al.(1971) and Berquist et al. (1972) from Detroit 6 cells (neoplastic human bone marrow) and HEL (human embryonic lung) cells, respectively, had the antigenic characteristics of $\mathrm{H}-3$ virus.

At the present time, it is well known that parvoviruses may persist in their natural hosts in spite of the presence of an impressive humoral immunity. Cell cultures prepared from tissues of infected animals therefore are frequently found to yield these viruses (Mayr et al., 1968; O'Reilly and Whitaker, 1969; Wozniak and Hetrick, 1969). Consequently, it is impossible to decide whether parvoviruses such as the minute virus of mice (MVM) or porcine parvovirus (PPV) which have come to our notice as contaminants in mouse adenovirus stocks (Crawford, 1966) or hog cholera virus (Horzinek et al., 1967; Mayr et al., 1968), respectively, had been already present in the original isolates or were picked up during passage of the latter viruses in latently infected cultures of mouse and pig cells. In any case, cell cultures prepared from tissues of conventionally raised, apparently healthy animals are always prone to yield parvoviruses. The latter fact is emphasized by the observation that apparently healthy animals may shed parvoviruses in their feces (Bouillant and Hanson, 1965; Csiza et al., 1971c; Storz and Leary, 1979). Three distinct parvoviruses - the bovine parvovirus (BPV) (Abinanti and Warfield, 1961), the minute virus of canines (MVC) (Binn et al., 1970), and the lapine parvovirus (LPV) (Matsunaga et al., 1977)-were isolated under these conditions.

In striking contrast to the frequency and readiness with which parvoviruses were recovered as contaminants from various biological materials, their identification generally posed a considerable problem whenever they were involved in clinically overt disease. Thus, both the syndromes of feline ataxia and feline enteritis had been known for almost 
a hundred years (Herringham and Andrewes, 1888; Zschokke, 1900) and had been studied in much detail during the first half of this century. Nevertheless, the feline parvovirus (FPV) responsible for both syndromes was isolated and characterized in the mid-1960s only (Johnson, 1964, 1965; Kilham and Margolis, 1966a; Johnson and Cruickshank, 1966; Johnson et al., 1967). Similarly, the syndrome of Aleutian disease of mink has been described by Hartsough and Gorham in 1956 and then was thought to be of genetic origin. In 1962, however, its transmissible nature was recognized almost simultaneously by two groups (Karstad and Pridham, 1962; Henson et al., 1962). In spite of the growing knowledge on the properties of parvoviruses, the causative virus was isolated in cell cultures in recent years only (Porter et al., 1977; Hahn et al., 1977a,b) and the definite physicochemical characteristics of the virion enabeling unambiguous classification of $\mathrm{ADV}$ with the parvoviruses were reported by Bloom et al. in 1980!

Comparable difficulties were encountered with goose parvovirus (GPV). The fatal disease resulting from infection with this virus is confined almost exclusively to goslings aged between 8 and 30 days. It was first described in Poland in 1962 by Wachnik and Nowaki. When the disease caused by the virus swept through Europe between 1962 and 1972 the related syndrome became known as "goose influenza" in Hungary, "virus hepatitis of geese" in Germany, "goose plague" in the Netherlands and "ascitic-hepato-nephritis" in France due to varying clinical symptoms and postmortem findings. Losses of up to $95 \%$ in affected geese flocks were reported (Kraus, 1965; van Cleef and Miltenberg, 1966; Derzy, 1967; Schettler, 1971a; Dannacher et al., 1974). Isolation in vitro and subsequent detailed characterization of the agent, however, indicated that all the different syndromes were caused by the same parvovirus (Schettler, 1973; Dannacher et al., 1974; Kisary, 1974; Kisary and Derzsy, 1974).

Finally, the very recent isolation and characterization of a parvovirus from dogs either suffering from severe enteritis or dying from acute heart failure (myocarditis) has to be mentioned. This virus-generally referred to as canine parvovirus (CPV)-is unrelated to the minute virus of canines (MVC) isolated previously by Binn et al. (1970). As described elsewhere in more detail (see Chapter 9), it represents a new, second, host-range variant of feline parvovirus. The first host-range variant of FPV-mink enteritis virus (MEV) - appeared in Canada more than 30 years ago (Schofield, 1949). Since then it has spread throughout the world and is now considered a major threat to mink-breeding colonies.

\section{B. Host Range of Parvoviruses}

In spite of the observations with the host-range variants of FPV the history of isolations of the various parvoviruses is suggestive for their host range and, hence, for their grouping within the genus within the 
TABLE I. The Origin of Autonomous Parvoviruses

\begin{tabular}{|c|c|c|c|}
\hline Virus & Vernacular name & Source of first isolation & Natural host \\
\hline RV & Rat virus & Rat neoplastic tissues & Rats \\
\hline RTV & - & Rat cell line & Rats (?) \\
\hline $\mathrm{H}-1$ & - & Human tumors $^{a}$ & Rats, man (?) \\
\hline $\mathrm{HB}$ & - & Human fetal tissues $^{a}$ & $\operatorname{Man}(?)$ \\
\hline MVM & Minute virus of mice & Mouse adenovirus stock & Mice \\
\hline \multicolumn{4}{|l|}{ FPV: } \\
\hline FPLV & $\begin{array}{l}\text { Feline parvovirus: feline } \\
\text { panleukopenia virus }\end{array}$ & Feline tissues & Cats \\
\hline MEV & Mink enteritis virus & Mink tissues & Mink \\
\hline $\mathrm{CPV}$ & Canine parvovirus & Canine feces & Dogs \\
\hline MVC & Minute virus of canines & Canine feces & Dogs \\
\hline BPV & Bovine parvovirus & Bovine feces & Cattle \\
\hline PPV & Porcine parvovirus & $\begin{array}{l}\text { Primary porcine cell } \\
\text { cultures }\end{array}$ & Swine \\
\hline GPV & Goose parvovirus & Goose tissues & Geese \\
\hline $\mathrm{ADV}$ & Aleutian disease virus & Mink tissues & Mink \\
\hline LPV & Lapine parvovirus & Rabbit feces & Rabbits \\
\hline TVX & - & $\begin{array}{l}\text { Human permanent cell } \\
\text { line }\end{array}$ & Rats (?) \\
\hline LuIII & - & $\begin{array}{l}\text { Human permanent cell } \\
\text { line }\end{array}$ & Unknown \\
\hline
\end{tabular}

${ }^{a}$ Isolated via inoculation of tissue homogenates into newborn hamsters.

helper-independent, autonomous parvoviruses. However, additional factors such as, for example, the incidence of antibodies in populations of the various species and a thorough comparison of viral antigens are necessary to obtain a reliable picture. The synopsis of such an analysis is given in Table I. It clearly indicates that, with very few exceptions which have to be discussed later, individual antigenically distinct parvoviruses apparently are limited to one natural host.

\section{ANTIGENIC STRUCTURE AND SEROLOGIC RELATIONSHIP}

Parvoviruses are rather simple particles consisting of not more than three structural proteins (Johnson, Chapter 7 of this volume). These proteins also share overlapping peptide sequences (Tattersall et al., 1977). Some of the polypeptides probably are present in precursors of the mature virion only and there is preliminary evidence (Majaniemi et al., 1981) that the capsid of the infectious particle of parvovirus LuIII might consist of multiple copies of one single polypeptide. It may be expected, therefore, that the mature parvovirus particle is of rather homogeneous antigenicity.

The antigen of the mature virion $(110 \mathrm{~S}, \rho=1.41 \mathrm{~g} / \mathrm{ml}$ in $\mathrm{CsCl}$ ) can be detected and identified by neutralization tests, by hemagglutination 
and hemagglutination inhibition, as well as by complement fixation. The extent to which the mature virion is antigenically related to the "dense" or "heavy" infectious virion (110S; $\rho=1.44-1.47 \mathrm{~g} / \mathrm{ml})$, to the defective or incomplete particles $(70-90 \mathrm{~S} ; \rho=1.34-1.39 \mathrm{~g} / \mathrm{ml})$, or to empty capsid structures $(70 \mathrm{~S} ; \rho=1.32 \mathrm{~g} / \mathrm{ml})$, is still unknown. All these types of particles react also in hemagglutination inhibition and complement fixation tests. Whether they can be distinguished serologically like D and L antigens of the infectious picornavirus particle and its corresponding empty capsid has not been investigated.

\section{A. Hemagglutination and Hemadsorption}

With exceptions of Aleutian disease virus (ADV) (Porter and Cho, 1980) and goose parvovirus (GPV) (Schettler, 1973; Kisary and Derzsy, $1974)$ the ability to agglutinate red blood cells of at least one animal species is a common characteristic of all agents listed in Table I. Due to the simple structure of the virus particle the hemagglutinating entity is identical with the virus capsid structure. Empty capsids, incomplete particles, as well as the two density variants of the infectious virion therefore are able to agglutinate suitable erythrocytes. Because the polypeptide composition of these particles differs /cf. Johnson, Chapter 7 of this volume), it could be assumed that the ability to hemagglutinate might also vary. In fact, it has been reported that the "heavy" $(1.44-1.46 \mathrm{~g} / \mathrm{ml})$ variant of the infectious virion of several parvoviruses has a lower specific hemagglutinating activity than the empty capsid or the "light" mature virion (Clinton and Hayashi, 1976; Tattersall, 1978a; Kongsvik et al., 1978). Interpretation of such results, however, depends on parameters like the purity of virus suspensions, the absence of virus aggregates, and the concentration of particles, none of which are easily controlled. The available results therefore are still far from being conclusive.

The parvovirus hemagglutinin is as resistant as the infectious virion. For various parvoviruses it proved to be stable from $\mathrm{pH} 2$ through $\mathrm{pH} 11$ when the particles were incubated at 4, 25, and $37^{\circ} \mathrm{C}$ (Green, 1965; Siegl et al., 1971). With increasing temperature, however, a gradual fall of HA titers of the treated virus suspensions could be observed. This became particularly evident at extreme $\mathrm{pH}$ values. At $\mathrm{pH} 5$ to 7 , on the other hand, the active hemagglutinin could still be demonstrated after incubation at $80^{\circ} \mathrm{C}$ for $30 \mathrm{~min}$ to $2 \mathrm{hr}$. Treatment with organic solvents such as ether and chloroform, or with various alcohols also does not affect the hemagglutinin (for reference see Siegl, 1976). Similarly, proteolytic enzymes (e.g., trypsin, chymotrypsin, and papain) proved without destructive effect (Green, 1964; Kongsvik and Toolan, 1972b; Siegl et al., 1971; Siegl, 1976). On the contrary, a brief treatment of $\mathrm{H}-1$ virus with papain (Kongsvik and Toolan, 1972) or with ficin (Kongsvik et al., 1974) even enhanced hemagglutination. These results were obtained with unpurified 
virus suspension of undefined particle composition. Therefore, they cannot be related to the results of the more recent biochemical studies which show that part of the polypeptides contained in the two buoyant density variants of the infectious parvovirus particle are in fact cleaved by both trypsin and chymotrypsin in vitro (Kongsvik, 1972b; Clinton and Hayashi, 1976; Tattersall 1978a; Kongsvik et al., 1978).

The effect of formaldehyde, glutaraldehyde, and $\beta$-propiolactone on the hemagglutinins of parvoviruses (Kongsvik et al., 1974; Scott, 1980; Siegl, unpublished) mostly depend on the temperature of reaction. Under carefully controlled conditions none of these agents demages the hemagglutination or the antigenicity of the particles even though infectivity is readily abolished.

The counterpart of the viral hemagglutinin-the receptor at the surface of the agglutinated red blood cell-has been assumed to be a glycoplipid structure containing $\mathrm{N}$-acetylneuraminic acid linked with carbohydrates and fatty acids (Cocuzza and Russo, 1969). This view is supported by the findings that pretreatment of erythrocytes with influenza virus or Newcastle disease virus, with receptor destroying enzyme (RDE) of bacterial origin, with lipid solvents, or with periodate rendered them nonagglutinable for parvoviruses (Moore, 1962a; Payne et al., 1964; Cocuzza and Russo, 1969; Hallauer et al., 1972). Formaldehyde, glutaraldehyde, and trypsin, on the other hand, proved to be without effect in these studies. Somewhat contradictory results were reported more recently by Mochizuki et al. (1978). These authors observed that the receptor for FPV on porcine erythrocytes was almost completely inactivated by trypsin, $\mathrm{KIO}_{4}$, $\alpha$-amylase, and, to some extent, also by formaldehyde. In consequence, the receptor structure was supposed by these authors to have the characteristics of a glycoprotein.

As far as the reaction between hemagglutinin and receptors is concerned, the reversible sensitivity of $\mathrm{H}-1$ hemagglutination to $p$-chloromercurybenzoate suggests that virus-bound sulfydryl groups could play an important role (Castro et al., 1971a,b; Kongsvik and Toolan, 1972b). The most critical parameters in the reaction of parvoviruses with suitable red blood cells, however, are temperature and $\mathrm{pH}$. In some instances skillful control of these parameters even can be used to distinguish between antigenically closely related viruses. For example, feline panleukopenia virus (FPLV) preferentially agglutinates pig erythrocyes at $\mathrm{pH} 6.5$, whereas $\mathrm{CPV}$, the canine variant of FPV, shows considerable hemagglutination activity at pH 7.2 (Carmichael et al., 1980; Tratschin et al., 1982). Likewise, FPLV and the mink variant MEV agglutinate pig erythrocytes almost exclusively at $4^{\circ} \mathrm{C}$. CPV again reacts effectively with the same type of cells also at room temperature (Tratschin et al., 1982). A reaction temperature around $+4^{\circ} \mathrm{C}$ was also found indispensable for hemagglutination by the minute virus of canines (MVC) (Binn et al., 1970) as well as for the lapine parvovirus (Matsunaga et al., 1977). For all other hemagglutinating parvoviruses the reaction apparently is completed within $2-4 \mathrm{hr}$ 
TABLE II. The Most Appropriate Conditions for the Detection and Quantitation of Parvoviruses by Hemagglutination

\begin{tabular}{lllc}
\hline \multicolumn{1}{c}{ Virus } & Erythrocytes: species of origin & $\mathrm{pH}$ & $\begin{array}{c}\text { Temperature } \\
\left({ }^{\circ} \mathrm{C}\right)\end{array}$ \\
\hline RV & Guinea pig and human O & $7.2^{a}$ & $20^{b}$ \\
RTV & Guinea pig and human O & 7.2 & 20 \\
H-1 & Guinea pig and human O & 7.2 & 20 \\
HB & Guinea pig & 7.2 & 20 \\
MVM & Guinea pig & 7.2 & 20 \\
FPV: & Pig & 6.5 & 4 \\
FPLV & Pig & $6.5-7.0$ & 4 \\
MEV & Pig and rhesus monkey & 7.2 & $4-20$ \\
CPV & Rhesus monkey & 4.2 & 20 \\
MVC & Guinea pig and human O & 7.2 & 20 \\
BPV & Guinea pig and human O & 7.2 & 4 \\
PPV & Guinea pig & 7.2 & 20 \\
LPV & Guinea pig and human O & 7.2 & 20 \\
TVX & Guinea pig and human O & 7.2 & \\
LuIII & $\quad$ No hemagglutination demonstrable \\
GPV & No hemagglutination demonstrable \\
ADV & \multicolumn{2}{c}{} \\
\hline
\end{tabular}

${ }^{a}$ Buffers in the range of between $\mathrm{pH}$ 6.8-7.4 were used by various authors. According to personal experiences $\mathrm{pH} 7.2$ is a good compromise.

$b$ In general, reaction was allowed to proceed at "room temperature." In some instances higher titers may be obtained during incubation at $4^{\circ} \mathrm{C}$.

at room temperature. Nevertheless, slightly higher titers are frequently recorded after incubation in the refrigerator overnight (Mayr et al., 1968; Bachmann, 1971; Bates et al., 1972; Mengeling, 1972; Inaba et al., 1973a,b).

Table II summarizes the most convenient hemagglutination conditions for the various parvoviruses. It is evident that the great majority of these viruses agglutinates guinea pig erythrocytes at room temperature. Rhesus monkey or African green monkey red blood cells, on the other hand, are suitable for MVC and CPV, whereas FPLV and MEV are easily detected with pig erythrocytes. All the latter viruses hemagglutinate preferentially at $4^{\circ} \mathrm{C}$. They elute from the red blood cells as soon as the temperature is raised to 20 or $37^{\circ} \mathrm{C}$; yet, the erythrocytes remain agglutinable and the reaction is reversible upon reincubation at refrigerator temperature.

For many of the viruses listed in Table II erythrocytes of as many as 19 different animal species have been tested for suitability in the heagglutination reaction (Toolan, 1976; Siegl, 1976; Porter and Cho, 1980; Mengeling, 1981; Siegl, Chapter 9 of this volume). In some of these investigations it was also proposed that particular isolates of antigenically closely related viruses can be distinguished on the basis of their hemagglutination pattern. It was realized, however, that reliable results can only be obtained under strictly controlled test conditions. In this respect, 
minimal prerequisites are standardization of virus suspensions and the use of a single batch of erythrocytes in all comparative experiments (Toolan, 1967b; Hallauer et al., 1972). The importance of the latter parameter is sufficiently illustrated by the frequent observations in routine diagnostic laboratories that hemagglutination titers of one and the same virus suspension may vary with the donor animal of the erythrocytes (e.g., Carmichael et al., 1980). In the case of PPV it was found that the extent to which this virus reacts with chicken erythrocytes depends on both the genetic composition (Cartwright et al., 1969; Morimoto et al., 1972; Pini, 1975; Ruckerbauer et al., 1978) and the age of the donor animal.

Closely related to the ability of parvoviruses to agglutinate red blood cells of various species is the phenomenon of hemadsorption. The respective results, however, are rather inconsistent (Kilham and Olivier, 1959; Portella, 1964; Cartwright et al., 1969; Hallauer et al., 1972; Hinaidy et al., 1979). Portella (1964) reported that in tissue cultures infected with RV, H-1, or H-3 virus only those cells proved to be infected to which guinea pig erythrocytes attached. According to electron micrographs the attachment of the erythrocytes to the cellular membranes was directly mediated by virus particles. Portella therefore recommended hemadsorption as a suitable and rapid means to detect virus infected cells. In contrast, rather slight hemadsorption was observed with BPV in cell cultures exhibiting low degree CPE (Hinaidy et al., 1979) and binding of guinea pig red blood cells to cell cultures infected with KBSH virus took place only after the cell associated virus had reached rather high HA titers (Hallauer et al., 1972). These discrepancies can be explained on the basis of the replication behavior of parvoviruses. Whereas enveloped hemagglutinating viruses mature by budding from the cell membrane, parvoviruses are replicated within the nucleus of an infected cell. The great majority of progeny virions are released upon the final disintegration of the host cell only. They then associate with unoccupied receptor structures both at the surface of intact cells and of cell debris and thus provide the substrate for the adsorption of erythrocytes.

The binding of progeny parvovirus particles to the cell detritus is a well-known phenomenon. During purification of the viruses this fact is allowed for by the use of receptor destroying enzyme (Salzman and Jori, 1970; Siegl et al., 1972; Tattersall et al., 1976) or treatment with buffer solutions of pH 8.0 to 9.0 (Hallauer and Kronauer, 1965; Gierthy et al., 1974) to dissociate the virus-receptor complex.

\section{B. Hemagglutination Inhibition}

Hemagglutination inhibition (HI) is the most convenient means of identifying the great majority of autonomous parvoviruses. This serological technique has been extensively used to investigate the antigenic relationship between individual viruses and to screen sera for the presence 
of antiviral antibodies as diagnostic indicator of a past infection. In both cases, however, the respective results can only be relied upon if hemagglutination conditions are sufficiently standardized (Hallauer et al., 1972; Joo et al., 1976b; Carmichael et al., 1980). Moreover, HI-tests are extremely sensitive to the presence of nonspecific inhibitors. These substances have been demonstrated in sera of humans and of almost all animal species so far tested (Moore, 1962b; Lum, 1970a,c; Hallauer et al., 1972; Joo et al., 1976b; Siegl and Kronauer, 1980). They may be present in extraordinarily high concentration and sometimes were still found in serum dilutions of 1:640! The nature of these inhibitors is largely unresolved. They resist heating to $56^{\circ} \mathrm{C}$ for $30 \mathrm{~min}$. Pretreatment of sera with $\mathrm{RDE}$, trypsin, sodium periodate, ether, or $\mathrm{MnCl}_{2}$ was found to yield inconsistent results. The most reliable technique of removing the substances from sera consists in extraction with Kaolin (Clarke and Casals, 1958). Even under these conditions, however, HI-titers of up to 1:80 can still be due to the presence of "inhibitory substances" rather than reflecting a low antibody titer. A second parallel extraction of the serum sample under investigation or more subtle techniques such as column chromatography and velocity sedimentation then can be used to reach an unambiguous decision.

To the best of our knowledge, the serum inhibitors dealt with so far are nonspecific, i.e., they indiscriminately inhibit hemagglutination by various parvoviruses. This is apparently not true for that inhibitor of $\mathrm{H}$ 1 hemagglutination which has been isolated from human placentas (Toolan 1964, 1968). The substance was purified and characterized by Usatequi-Gomez (1965), Karasaki et al. (1965), and Usatequi-Gomez and Morgan (1968) as a glycoprotein with many properties of a macroglobulin. It interfered specifically with hemagglutination by $\mathrm{H}-1$ virus. Hemagglutination by the antigenically closely related HT virus was only occasionally inhibited and hemagglutination by the serologically unrelated $\mathrm{HB}, \mathrm{RV}$, and $\mathrm{H}-3$ viruses was not affected at all.

On the basis of HI-tests, the hemagglutinating autonomous parvoviruses can be separated into 12 distinct groups (Table III). These groups apparently share no HI-antigen in common. A one-sided serologic relationship between individual groups (e.g., between TVX and $\mathrm{H}-1$ ) has been occasionally reported (cf. Lum and Schreiner, 1963; Hallauer et al., 1971). It cannot be excluded, however that such observations reflect a contamination of the antigens used to raise the antisera rather than a true antigenic relationship between the viruses concerned. Contamination of antigens thereby may have resulted from the use of primary cell cultures prepared from the tissues of latently infected animals (Mayr et al., 1968; O'Reilly and Whitaker, 1969) or from cell cultures contaminated in the laboratory (Wozniak and Hetrick, 1969; Hallauer et al., 1971). It is therefore also conceivable that the "new" serotype of BPV described so far only by Inaba et al. (1973a) and compared exclusively to BPV reference strains represents an already well-known parvovirus (PPV?). 


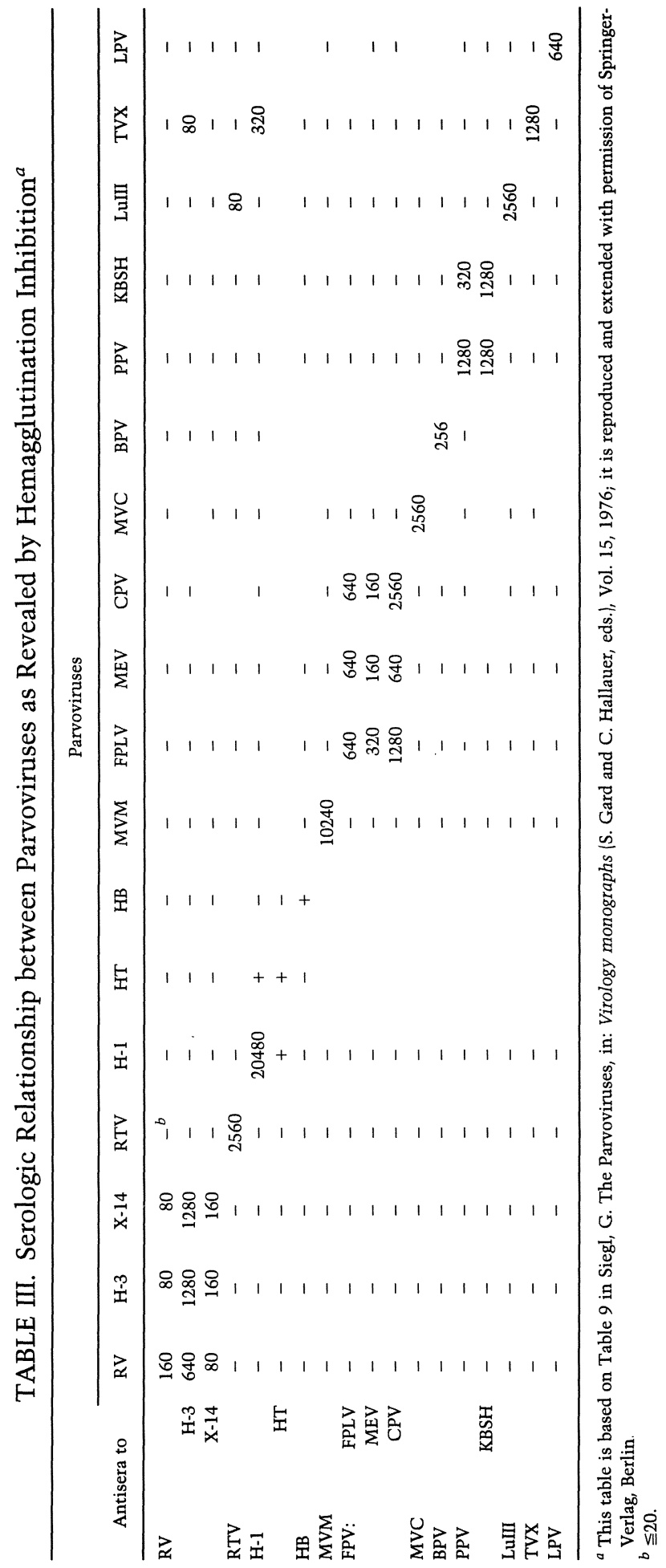


In general, virus strains belonging to a certain antigenic group cannot be distinguished by HI. The validity of this observation was also claimed for the host-range variants of FPV, i.e., for FPLV, MEV, and CPV (Carmichael et al., 1980; Lenghaus and Studdert, 1980). Following preadsorption of anti-CPV serum with FPLV antigen, however, Flower et al., (1980) have provided evidence for the existence of a specific extra antigenic determinant in CPV, Tratschin et al. (1982) also could show that, in agreement with the results of neutralization tests, antisera prepared against FPLV or MEV do not distinguish between the three viruses in HItests. Antisera raised against CPV, on the other hand, react with the homologous virus at considerabley (8 to 64 times) higher dilutions than the two heterologous agents.

To the extent tested, antisera against the two non hemagglutinating autonomous parvoviruses $\mathrm{ADV}$ and $\mathrm{CPV}$ did not interfere with hemagglutination by some of the viruses listed in Table III.

\section{Serum Neutralization}

As far as the serologic relationship between the viruses grouped in Table III is concerned, cross neutralization brought about no new points of view. No antigen in common to the various viruses could be revealed by such tests (Moore, 1962b; Portella, 1963; Lum and Schreiner, 1963; Toolan, 1964; Crawford, 1966; Gorham et al., 1966; Johnson, 1967b; Johnson et al., 1967; Scott et al., 1970b; Cross and Parker, 1972; Storz et al., 1972; Inaba et al., 1973b; Joo et al., 1975; Siegl, 1976; Tratschin et al., 1982). Slight antigenic differences between individual isolates of one and the same virus, however, apparently are more readily detected than by means of HI. This has been observed in studies within RV, H-3, and L-S virus (Moore, 1962b; Portella, 1963; Lum and Schreiner, 1963) where immune sera showed considerably higher titers for the homologous than for the heterologous virus. Similarly, Lenghaus and Studdert (1980) reported that, by serum neutralization, CPV proved closely related but clearly distinguishable from wild-type and vaccine strains of FPLV. The results of Tratschin et al. (1982) are in agreement with these findings.

Of the two nonhemagglutinating parvoviruses GPV and ADV the goose parvovirus was shown by neutralization tests to be unrelated to MVM, PPV, BPV, and $\mathrm{H}-1$ virus (J. Kisary, personal communication). Moreover, cross neutralization with the French isolate, the isolate from Hungary, from the Netherlands, and one from the USSR suggested that probably all GPV strains isolated in Europe are antigenically identical (Dannacher et al., 1974; Kisary, 1974). Neutralization tests with ADV, on the other hand, present a special and so far unresolved problem. As will be discussed elsewhere in more detail, ADV infection of mink results in the formation of large amounts of circulating antiviral antibodies. These antibodies could be shown by electron microscopy to react with 
ADV. The resulting virus-antibody complexes, however, remain infectious for both susceptible animals and sensitive cell cultures. Such results were obtained with sera from chronically infected mink, with sera of mink with a nonpersistent ADV infection, as well as with sera from ferrets with ADV antibody and no disease (Larsen and Porter, 1975; Porter and Cho, 1980).

Neutralization tests have been reported to be more sensitive than $\mathrm{HI}$ tests in the detection of antiviral antibody (Johnson and Collings, 1971; Joo et al., 1975; Siegl and Kronauer, 1980). This is especially true for plague-reduction tests where sera nonreactive in $\mathrm{HI}$ can frequently be diluted several-hundred-fold before end titers in neutralization are reached (Siegl and Kronauer, 1980). On the basis of assay systems which detect viral infectivity via the induction of cytopathologic changes in the infected monolayer or by screening for intranuclear inclusion bodies, however, neutralizing serum antibodies frequently are found to be of the same magnitude as antibody titers read by HI (Goto, 1975; Konishi et al., 1975; Mochizuki et al., 1978).

\section{Immunofluorescent Studies}

Immunofluorescent staining has successfully been used to detect parvovirus antigens in tissues of infected animals (cf. Csiza et al., 1971b; Storz and Bates, 1973; Mengeling et al., 1975; Carmichael and Binn, 1981) to study the replication of parvoviruses in cell cultures (Mayor and Ito, 1968; Cole and Nathanson, 1969; Siegl and Gautschi, 1973; Bachmann and Danner, 1976; Hahn et al., 1977a,b), and to follow synthesis and accumulation of viral polypeptides in infected cells (Croft et al., 1974). IF-staining is very helpful in determining infectivity titers of parvoviruses. It is usually much easier and much less time consuming to detect single infected cells by this technique than by screening cultures infected with end point dilutions for, e.g., FPV-specific intranuclear inclusion bodies (King and Croghan, 1965; Mochizuki et al., 1978; Siegl and Kronauer, 1980). In consequence, much higher virus titers are usually recorded and the apparent infectious unit consists of less virus particles. This, in return, affects the results of neutralization tests (Scott et al., 1970b). Moreover, under conditions where virus infections neither lead to cytopathologic alterations in the unstained monolayer nor to formation of inclusion bodies, IF-staining is the only reasonable means to detect viral replication. At the present time, this does apply to the propagation of $\mathrm{ADV}$ in vitro. Infectivity of the latter virus is titrated by a fluorescent focus assay (Hahn et al., 1977a,b; Porter and Cho, 1980).

IF-staining has also been used to investigate the antigenic relationship of several parvoviruses. Cross and Parker (1972) infected rat embryo cell cultures with RV, H-1, and MVM and, by cross-IF staining with the respective antisera, found these viruses to share a common antigen (s). 
Similarly, Black et al. (1979) and Eugster (1980) reported on an antigen in common to CPV and PPV which can be revealed by fluorescent antibody staining. Most authors, however, agree that the latter two viruses are antigenically unrelated (for reference see Chapter 9). In our laboratory repeated attempts to reveal a common antigen for PPV and CPV by indirect IF-staining have failed (G. Siegl and G. Kronauer, unpublished).

On the other hand, fluorescent antibody staining indicated that GPV is serologically unrelated to RV, H-1, MVM, RTV, PPV, BPV, FPV, TVX, and LuIII virus (P.A. Bachmann, personal communication).

\section{E. Complement Fixation and Further Serologic Techniques}

Complement fixation (CF) has been repeatedly used to identify and to quantitate parvovirus antigens (Kääriäinen et al., 1966; Cross and Parker, 1972, Schettler, 1973; Ruckerbauer et al., 1978; Mochizuki et al., 1978). In such studies it was found that CF reactivity is associated with the well-known types of virus particles detected also by infectivity assay and/or hemagglutination. The time course the appearance of CF-antibody subsequent to the contact with parvovirus antigens has only been studied in rabbits infected with FPLV. In this animal the CF antibody response paralleled the behavior of $\mathrm{HI}$ and SN titers but was distinctly lower. Finally, in agreement with $\mathrm{HI}$ and SN tests, attempts to detect a common CF-antigen for some of the viruses listed in Table III failed (Cross and Parker, 1972). It proved also impossible to discriminate between individual strains of FPLV by this technique (Mochizuki et al., 1978).

Of further serologic techniques applied to the study of parvoviruses, counter-immune electrophoresis (CIEP) was found to be the most useful approach to detect and to quantitate ADV antigen in the serum of infected mink (Cho and Ingram, 1972, 1973, 1974; Bloom et al., 1975; Notani et al., 1976; Porter and Cho, 1980). Immunodiffusion finally was used by Joo et al. (1978) in the study of PPV antigenicity, and, very recently, Flower et al. (1980) have applied the latter technique to reveal an extra antigenic determinant in CPV by means of which it can be distinguished from FPLV and MEV.

\section{PROPAGATION AND ASSAY SYSTEMS}

\section{A. Dependence of Viral Replication on Cell Physiologic State}

Although the viruses dealt with in this review are referred to as nondefective or autonomous parvoviruses, they depend for replication on cellular helper functions. These functions are expressed only transiently in late S- or early G-2 phase during the life cycle of a susceptible cell (Tennant et al., 1969; Hampton, 1970; Tattersall, 1972; Rhode, 1973; 
Siegl and Gautschi, 1973). Our present state of knowledge concerning the characteristics of the cellular functions as well as the steps in virus replication governed by them will not be discussed in this context. Here I shall only summarize some basic in vitro observations and shall place emphasis on the implications of this specific virus-cell relationship for the propagation and assay of parvoviruses.

In 1965 Margolis and Kilham related the pronounced destructive action of viruses like RV and $\mathrm{H}-1$ in rapidly proliferating tissues of newborn rodents to their affinity for cells undergoing mitosis. At about the same time Johnson $(1965,1967$ a) attempted in vitro propagation of feline panleukopenia virus. He then listed a number of critical parameters either stimulating or hampering replication of the virus in primary feline kidney cells. All those parameters which affected mitotic activity within the cell cultures (e.g., density of the cell monolayer, the quality of sera used to supplement growth medium, or the temperature of incubation) apparently favored virus replication whenever they increased the mitotic activity. Since these early observations, comparable cultural prerequisites have been established for in vitro propagation of every autonomous parvovirus studied in greater detail, i.e., for RV, H-1, FPV, PPV, BPV, ADV, GPV, LPV, RTV, TVX, and LuIII virus (Cole and Nathanson, 1969; Ledinko et al., 1969; Tennant et al., 1969; Hallauer et al., 1972; Tattersall, 1972; Storz and Bates, 1973; Lubeck and Johnson, 1976; Hahn et al., 1977a,b; O'Shea and Studdert, 1978; Kisary, 1979; Carmichael and Binn, 1981; Johnson and Spradbrow, 1979). In particular it was found essential to either infect cultures "not yet completely confluent" or to add the virus already at the time of seeding the cells. At rather low multiplicity of infection, for example, in cultures inoculated with end point dilutions of virus suspensions, even this technique may fail to stimulate viral replication to a degree inducing CPE before the monolayer reaches confluence. In such cultures, in which mitotic activity has slowed down due to density-dependent inhibition of cellular growth, viral replication can be activated again by trypsinization and splitting of the cells at a reasonable rate (Hallauer et al., 1972; Johnson et al., 1974).

In susceptible culture systems the ability of the cells to proliferate and to pass actively through the division cycle thus is the predominant prerequisite of successful virus replication. If this is taken into account, some of the observations of Cole and Nathanson (1969) and Ledinko et al. (1969) concerning the replication of RV and $\mathrm{H}-1$ virus in L-cells and in the diploid cell line Wi-26, respectively, can probably be explained. Judged on the production of infectious virus particles, replication of these viruses in the cell systems originally appeared to be incomplete or even abortive. Fluorescent antibody staining, however, revealed that viral replication proceeded successfully in a small proportion of cells apparently undergoing active growth.

Finally, it has to be mentioned that a cell's ability to support replication of a parvovirus-in other words, its susceptibility or resistance to 
infection-seems to be a function of its metabolic capacity as expressed under the control of differentiation and development. This conclusion can be drawn from in vitro experiments conducted by Tattersall (1978b). Using murine teratoma cells he could show that, within the pathway these cells can differentiate, only one type of cell evolved which supported replication of MVM.

\section{B. Host Cell Range and Cultivation}

It is obvious that the dependence of parvovirus replication on helper functions expressed under the control of cellular differentiation has a direct influence on the in vitro host range of the viruses. This host range therefore is both of basic theoretical and of practical laboratory significance. In most of the studies available to date, however, mere practical points of view prevailed and investigations were mainly centered at the question whether a certain parvovirus can be propagated to high titers in a readily accessible and easily maintainable culture system. The respective published laboratory experience is condensed to Table IV. To the best of our knowledge, this table lists the most appropriate culture systems for the various viruses.

As is evident, most of the viruses can be propagated in primary and secondary cultures derived from tissues of embryos or neonates of their natural animal host. Moreover, permanent cell lines originating from such sources in general proved to be very useful. For some of the parvoviruses, e.g., RTV, MVM, BPV, MVC, LPV, and GPV, primary and permanent cell cultures derived from tissues of their natural host apparently are the only susceptible ones (Crawford, 1966; Binn et al., 1970; Parker et al., 1970a; Hallauer et al., 1971, 1972; Storz and Bates, 1973; Kisary, 1974; Matsunaga et al., 1977). These culture systems frequently also have to be used to achieve isolation of RV, PPV, and FPLV under routine diagnostic conditions (Kilham and Olivier, 1959; Lum and Schreiner, 1963; Payne et al., 1964; Mayr et al., 1968; Johnson, 1964). Of these viruses, however, variants are known which can be readily propagated in cells of widely unrelated hosts. Thus, $\mathrm{H}-3$ virus-antigenically closely related to $\mathrm{RV}$ - can be grown in cell lines of human origin (Toolan and Ledinko, 1965; Hallauer et al., 1972) and related viruses were recovered from a cloned line of Detroit-6 cells (neoplastic human bone marrow) (Melnik et al., 1971) as well as from human embryonic lung (HEL) cells (Berquist et al., 1972). Likewise, Hallauer et al. $(1971,1972)$ found the great majority of parvoviruses isolated as contaminants of permanent human cell lines (e.g., KB, HeLa, HEp-2, and FL-Amnion) to be serologically indistinguishable from PPV. Attempts to isolate PPV from tissues of infected pigs in cells of human, monkey, and rat origin originally had failed (Mayr et al., 1968), but Cartwright et al. (1969) succeeded in adapting PPV to growth in a variety of human cell lines. Finally, the determination of the 
TABLE IV. The Most Convenient in Vitro Systems for the Propagation of Parvoviruses $^{a}$

\begin{tabular}{|c|c|c|c|}
\hline Virus: & Strain & Primary cultures & Permanent cell lines \\
\hline \multirow[t]{5}{*}{ RV } & & Rat embryonic & Rat nephroma (Babcock and Southam) \\
\hline & $\mathrm{H}-3$ & Rat embryonic & NB (human transformed, Shein \& Enders) \\
\hline & $\mathrm{X}-14$ & Rat embryonic & Rat nephroma \\
\hline & L-S & Rat embryonic & Rat nephroma \\
\hline & HER & Rat embryonic & Rat nephroma \\
\hline RT & & n.t. ${ }^{b}$ & AT (rat; Tournier) \\
\hline $\mathrm{H}-1$ & & Rat embryonic & NB (human transformed, Shein \& Enders) \\
\hline MVM & & Mouse and rat embryonic & A-9 (mouse L-cells) \\
\hline \multirow[t]{3}{*}{ FPV: } & FPLV & Feline kidney & CRFK (feline kidney) \\
\hline & MEV & Feline kidney & CRFK \\
\hline & $\mathrm{CPV}$ & Feline and canine kidney & $\begin{array}{l}\text { CRFK; MDCK (canine kidney), } \\
\text { A } 72 \text { (canine neoplastic) }\end{array}$ \\
\hline \multirow[t]{3}{*}{ PPV } & & Fetal or neonatal porcine & PK-14 (porcine kidney) \\
\hline & & kidney and testicle & SK (swine testicle) \\
\hline & KBSH & ? & HeLa, KBS (human neoplastic) \\
\hline BPV & & $\begin{array}{l}\text { Bovine fetal lung, spleen and } \\
\text { kidney }\end{array}$ & Buffalo lung fibroblast \\
\hline MVC & & ? & WRCC (canine) \\
\hline $\mathrm{ADV}$ & & $\begin{array}{l}\text { Mink, ferret and feline } \\
\text { kidney }\end{array}$ & CRFK (feline kidney) \\
\hline LPV & & Rabbit kidney & RK (rabbit kidney) \\
\hline GPV & & Goose embryo, duck embryo & ? \\
\hline TVX & & $?$ & HeLa, KB (human neoplastic) \\
\hline LuIII & & $?$ & $\begin{array}{l}\text { HeLa, NB (human transformed, Shein \& } \\
\text { Enders) } \\
\text { Chimpanzee liver (Douglas) }\end{array}$ \\
\hline & & & Chimpanzee liver (Do \\
\hline
\end{tabular}

${ }^{a}$ For references the reader is referred to the text as well as to the specific reviews (Toolan, 1968; Siegl, 1976; Porter and Cho, 1980; Mengeling, 1981; Siegl, Chapter 91.

${ }^{b}$ Not tested.

in vitro host cell range is one of the very few possibilities to distinguish CPV from FPLV and MEV. The latter two variants of the feline parvovirus have a rather limited host range and are routinely propagated in feline cells only. CPV, on the other hand and well in accordance with in vivo observations, was found to replicate exceptionally well in primary and permanent cultures of both feline and canine origin (Johnson and Spradbrow, 1979; Eugster, 1980; Lenghaus and Studdert, 1980; Carmichael et al., 1980; Tratschin et al., 1982).

Serological surveys and epidemiological observations (cf. Mengeling, 1981) clearly indicate that the natural host of PPV is the pig. Viruses like KBSH and comparable isolates (Hallauer et al., 1971, 1972) therefore may be regarded as host cell variants selected by cultivation in the laboratory. Similar considerations were drawn into account to explain the generation of CPV from FPV (see Chapter 9). In this special case the new host-range variant also established itself as pathogen in a so far unaffected species. In contrast to these two examples, however, the situation with $\mathrm{H}-1$ virus 
is not conclusive. This virus was found to replicate readily in human cells in vivo and in vitro (Toolan et al., 1965; Toolan and Ledinko, 1965; Toolan, 1968); yet, primary cultures of rat embryo cells support virus replication to the same extent (Moore, 1962a; Nicoletti et al., 1969) and there is evidence for a widespread dissemination of the agent in rat populations (Kilham and Margolis, 1969). Neither the in vivo nor the in vitro host range of $\mathrm{H}-1$ therefore provides helpful hints in the search for its natural host.

Similar difficulties are encountered with two of the parvoviruses isolated by Hallauer et al. (1971) from contaminated human cell lines. To date, LuIII virus could only be propagated in permanent cell lines of human and chimpanzee origin (Hallauer et al., 1972; Soike et al., 1976; Siegl and Gautschi, 1978) but antibodies to the virus could never be detected in sera of these species. TVX also was shown to replicate readily in various human cell lines. As with LuIII virus, no antibodies could be detected in human sera. Screening of rat sera, however, revealed HI-antibody titers as high as 1:1280 in 16 out of 50 sera (G. Siegl and G. Kronauer, unpublished). Whether the virus can replicate in rat cells in vitro still awaits testing.

There is sound reason to regard the viruses dealt with in the preceding paragraphs as easily cultivable parvoviruses. For each of the agents several susceptible culture systems have been described and, given incubation conditions stimulating cellular proliferation and mitosis, all viruses can easily be propagated. In contrast, at least two of the better characterized parvoviruses as well as a series of possible members of the autonomous parvovirus group are rather delicate with respect to cultivation. MVC, the canine virus isolated by Binn et al., in 1970, could only be propagated in the WRCC (Walter Reed canine cell) line. All parallel attempts to adapt the virus to growth in primary cells of dog, cat, mouse, rat, hamster, guinea pig, rabbit, pig, bovine, monkey, and human origin failed. Permanent lines of cells derived from the same species also proved insusceptible. Since that time many laboratories have tried to propagate the original isolate of MVC in canine cells or to recover the virus again in culture from fecal canine specimens. According to various personal communications all these attempts, including those undertaken in our own laboratory, were in vain. Impressed by these negative results R. H. Johnson (personal communication) assumes that MVC does not belong to the autonomous but rather, is a member of the helper-dependent parvoviruses. On the basis of such a hypothesis, propagation in the WRCC line could then have been possible due to a preexisting latent infection with, or the unrecognized presence in the inoculum of an adenovirus helper. The necessary critical experiment to test for this possibility consists in the inoculation of MVC into canine cells together with an adequate helper virus. This has not yet been attempted. It is also quite questionable whether the results of such an experiment would be conclusive. Brailovsky and Chany (1965), Chany and Brailovsky (1965), as well as Ledinko 
and Toolan (1968) have shown that, comparable to the situation with the dependoviruses, multiplication of autonomous parvoviruses like RV and $\mathrm{H}-1$ in inappropriate culture systems can be stimulated by coinfection with an adenovirus helper. The necessary critical helper function was found to be expressed late in adenovirus replication (Ledinko et al., 1969). Under its influence $\mathrm{H}-1$ virus replicated successfully both in human embryonic lung cells as well as in cells of the diploid human cell line Wi26 which otherwise did not support progressive virus growth.

In spite of the difficulties in interpretation apparently associated with the experiments suggested by R.H. Johnson, the idea might be worthwhile trying with the various noncultivable, parvoviruslike particles detected repeatedly during the past decade in human feces and sera (Cossart et al., 1975; Paver et al., 1973, 1974, 1975a,b; Paver and Clarke, 1976; Pattison et al., 1981; Serjeant et al., 1981). Samples containing these viruses are in general very rare and even a low degree of multiplication of the viruses-whether completely helper virus dependent or not-would be helpful in determining their characteristics and in facilitating the search for a susceptible culture system.

Besides the "priming" of an otherwise unsuitable cell culture system by coinfection with a helper adenovirus, an additional factor stimulating or inducing replication of poorly or even noncultivable parvoviruses could consist in a proper selection of the temperature of incubation. This procedure proved to be rewarding in studies with ADV. In spite of the fact that the body temperature of mink is $39^{\circ} \mathrm{C}$, frequent attempts to propagate $\mathrm{ADV}$ at $37^{\circ} \mathrm{C}$ failed or could not be reproduced (for reference see Hahn et al., 1977a). In 1977, however, Porter et al. succeeded in cultivating the virus in primary or permanent feline kidney cells at $31.8^{\circ} \mathrm{C}$. After 10 passages under these conditions of incubation, the temperature optimum shifted to $37^{\circ} \mathrm{C}$. In parallel, Hahn and co-workers (1977a) could adapt the highly virulent Utah-1 strain of ADV directly to growth in feline kidney cells at $37^{\circ} \mathrm{C}$ whereas virus strains of low virulence underwent abortive replication under the same conditions of cultivation. Porter and Cho (1980) recently reported that such less virulent ADV strains are even difficult to propagate at $31.8^{\circ} \mathrm{C}$; yet, they could be serially passaged when the temperature of incubation was further reduced to $28^{\circ} \mathrm{C}$. In all the in vitro experiments conduced so far. with ADV, the CRFK permanent line of feline kidney cells was found to be the best system for the propagation of the virus (Hahn et al., 1977a; Porter and Cho, 1980; Bloom et al., 1980). It is noteworthy, however, that primary mink and ferret cells were also quite susceptible. Finally, expression of ADV antigen has been observed by means of fluorescent antibody staining in guinea pig peritoneal macrophages and even in NB (simian virus 40-transformed newborn human kidney) cells (Hahn et al., 1977a). To what extent, if at all, accumulation of this antigen is indicative of synthesis of progeny infectious virus has not yet been tested. 
There are two additional points which have to be mentioned in context with the propagation of parvoviruses in vitro. The first concerns the transiency of virus replication as observed in several culture systems. It is closely related to the dependence of virus synthesis on actively growing cells. As lined out already under Section III.A and as is referred to again in the following chapter, virus replication is halted whenever cellular proliferation is arrested. In culture systems prone to reach a state of density-dependent inhibition of cellular growth, virus synthesis then might become completely undetectable. In general, this phenomenon is less evident during propagation of the viruses in permanent line cells than in primary or secondary cell cultures.

The final facet of parvovirus replication which has to be referred to concerns the strict cell association frequently observed with parvoviruses. Strict cell association, however, is not a stable characteristic of all parvovirus-cell systems. It can vary considerably both with the virus strain and the cell type used. Therefore, no generally valid rule can be established; rather, both the supernatant culture medium and the cellular extracts have to be assayed for presence of progeny virus at regular intervals to obtain reliable information on the distribution of the virus in the culture system of interest. For that purpose, cellular extracts can either be prepared by treatment of monolayers with alkaline glycine buffer according to Hallauer and Kronauer (1965) or by repeated freezing and thawing of cells followed by digestion with RDE or treatment with Freon.

\section{Cytopathology}

With only the exception of ADV, replication of the autonomous parvoviruses in one of the in vitro culture systems listed in Table IV is accompanied by cytopathologic changes. These virus induced cellular changes can be observed both in the unstained monolayer and after histologic staining. In the unstained monolayer they are in general characterized by diffuse granulation, rounding up of cells, detachment of single or groups of pyknotic cells and, finally, by complete destruction of the culture (Moore, 1962a; Toolan and Ledinko, 1965; Johnson, 1967a; Mayr et al., 1968; Parker et al., 1970a Binn et al., 1970; Hallauer et al., 1972; Storz and Bates, 1973; Matsunaga et al., 1977). Complete CPE, however, will only develop if a mitotically active cell sheet is inoculated at a sufficiently high multiplicity of infection. If this requirement is not met, i.e., if the infected monolayer reaches a state of density-dependent inhibition of cellular growth before infection has spread to the greater majority of a culture's cells, the cytopathologic changes are transient in nature (Johnson, 1965, 1967a; Lubeck and Johnson, 1967). Under the latter circumstances the virus-affected, pyknotic cells are lost from the cell sheet which then resumes an uninfected appearance and can be distin- 
guished from control cultures only on the basis of a more or less characteristic thinning. Detection of parvovirus replication by CPE, therefore, may require a careful, sometimes lengthy observation period and repeated subculturing may be necessary to continuously provide a source of actively proliferating cells.

In many of the early studies centered at the in vitro replication of parvoviruses, the time necessary for the development of clear CPE was reported to vary from two to 15 days. From the more recent studies in synchronized culture systems, however, we know that the shortest possible replication cycle of an autonomous parvovirus, that is to say, the time elapsing between infection of a susceptible cell in mid S-phase and the height of maturation of progeny virus, is about 8 to $10 \mathrm{hr}$ (Hampton, 1970; Rhode, 1973; Siegl and Gautschi, 1973a,b). After that period of time, phase contrast microscopy may already reveal early intranuclear changes consisting of a more or less prominent granulation. The full spectrum of cytopathology accompanying cellular death, however, will not develop before 24 to $48 \mathrm{hr}$ after infection.

In contrast to the delayed morphologic reaction of the parvovirusinfected cell as observed by light microscopy, histologic staining reveals virus-induced cytopathology at a much earlier stage. The changes are detectable by $\mathrm{H} \& \mathrm{E}$, May-Gruenwald-Giesma, or Feulgen staining. They consist in the generation of intranuclear Cowdry type-A inclusion bodies and have been described for $\mathrm{H}-1$, as well as for RV and related isolates (Dawe et al., 1961; Moore, 1962; Bernhard et al., 1963; Portella, 1963; Hampton, 1964; Mayor and Jordan, 1966; Nicoletti et al., 1969), for FPLV (Johnson, 1965; Goto and Ishiko, 1976; O'Shea and Studdert, 1978), PPV (Mayr et al., 1968; Cartwright et al., 1969), MVC (Binn et al., 1970), CPV (Johnson and Spradbrow, 1979; Gagnon and Povey, 1979), BPV (Storz and Warren, 1970), GPV (Kisary and Derzsy, 1974), and for LPV (Matsunaga et al., 1977). In an unsynchronized, randomly proliferating cell culture the first visible histologic changes become evident already between 8 and $12 \mathrm{hr}$ after infection (O'Shea and Studdert, 1978). In general, they consist in an enlargement of the nucleoli, which is followed by rarefaction of normal chromatin around the nucleoli and the replacement of normal chromatin by granular, mostly eosinophilic material. With progressing time, continued accumulation of granular material leads to margination of the cellular chromatin, to thickening of the nuclear membrane, and, finally, to the development of a homogeneous, mostly basophilic inclusion. At this stage the nucleoli are in general dislocated to the nuclear membrane.

An additional, different type of inclusion has been described for BPV (Inaba et al., 1973; Hinaidy et al., 1979; Leary and Storz, 1980). This type either consists of multiple round, eosinophilic to basophilic foci spread throughout the nucleus or of similar structures arranged along the nuclear membrane. The factors predisposing the development of the multifocal or the classical Cowdry type A inclusion in a BPV infected cell are un- 
known. On the basis of preliminary experiments with plague purified BPV, however, Leary and Storz (1980) have suggested that the genotype of the virus may play a significant role. Yet, additional parameters such as the actual cellular phenotype or the number of virus particles entering a cell may also influence the result of infection. In this context it has to be mentioned that the multifocal type of inclusion body has not yet been observed in tissues of infected animals.

According to fluorescent antibody staining, both the classical Cowdry type A inclusion and the multifocal inclusion body consist of an accumulation of parvovirus antigen. The structure of this antigen as well as its intranuclear distribution has been repeatedly analyzed by electron microscopy (Bernhard et al., 1963; Portella, 1964; Mayor and Jordan, 1966; Mayr et al., 1968; Al-Lami et al., 1969; Vincent, 1971; Siegl et al., 1972; Bates and Storz, 1974, O'Shea and Studdert, 1978; Leary and Storz, 1980). The most thorough ultrahistological study was conducted with $\mathrm{H}-1$ virus (Singer, 1975, 1976; Singer and Toolan, 1975; Singer and Rhode, 1977a,b, 1978). Singer and co-workers took into consideration the influence of the physiologic state of the infected cell as well as the genetic characteristics of the infecting virus. They also related ultrastructural observations to biochemical and immunocytochemical findings. Under the limitations of this review it is impossible to discuss the multitude of these investigators' ultrastructural observations in detail. Due to significant differences in the experimental design-parasynchronously rather than randomly growing cells were infected and analyzed-it is also difficult to relate the sequence of events recorded for $\mathrm{H}-1$ to the findings with other parvoviruses. Nevertheless, a general picture of the morphologic aspects of parvovirus replication can be deduced from the available studies:

The first specific ultrastructural changes are observed as early as 8 to $12 \mathrm{hr}$ after infection. In the case of $\mathrm{H}-1$ virus they consist of vacuolization of nucleolar fibrillar centers and are accompanied by the appearance of "full" and "empty" virus particles within the nucleolus. Involvement of the nucleolus early in the replication of parvoviruses has also been claimed for RV (Nicolletti et al., 1969) and for BPV (Bates and Storz, 1974). The subsequent, prominent accumulation of viral antigen, however, occurs outside the nucleolus. Most of this antigen in the form of assembled virus capsids is localized on nuclear euchromatin fibers. Immunocytochemical studies of $\mathrm{H}-1$ infected cells, however, also pointed to the presence of significant concentrations of $\mathrm{H}-1$ proteins not assembled into capsids, in condensing and marginating nucleolus-associated chromatin and in the extranucleolar heterochromatin. Whether predominantly "full" or "empty" particles finally accumulate in the nucleus seems to depend on the host cell type (Singer and Toolan, 1965). The host cell type apparently also determines whether the virus particles are randomly distributed throughout the nucleoplasm or whether cristalline arrays are formed (Al-Lami et al., 1969). Experiments with temperaturesensitive mutants of $\mathrm{H}-1$ virus, however, seem to indicate that the gen- 
otype of the infecting virus plays an additional role (Singer and Rhode, 1977a).

Fluorescent antibody staining of infected cells revealed that, in terminal stages of parvovirus replication, virus antigen is released from the nucleus into the cytoplasm. This observation is corroborated by ultrahistological studies where virus particles were found within the cytoplasm in the vicinity of nuclear pores at later phases of infection. Since at that time the nuclear membrane frequently shows signs of fragmentation, it is not clear whether the presence of virions in the cytoplasm is the result of an active transport process or reflects a passive release of progeny virions from a degenerating nucleus into a similarly degenerating cytoplasm.

\section{Persistently Infected Cell Cultures}

Latency and persistent infection are common features of the interaction of parvovirus with host cells. This applies both for the situation in vivo (cf. Section IV.D) and for propagation in vitro. In fact, many of the autonomous parvoviruses have been recovered when tissues latently infected in vivo were trypsinized and the cells were explanted (Kilham and Olivier, 1959; Mayr et al., 1968). Others apparently were introduced by chance into permanent cell lines in the laboratory and remained undetected throughout a great number of passages (Wozniak and Hetrick, 1969; Lum, 1970a,c:, Hallauer et al., 1971; Bonnard et al., 1976; Mengeling, 1975; Nettleton and Rweyemamu, 1980). In both cases the infected monolayers mostly showed a quite normal aspect. The contaminating virus was produced in rather low quantity and remained highly cell associated. Presence of infection therefore was indicated by not more than a slight degree of cellular degeneration similar to that characteristic for an aging, yet uninfected monolayer. Occasionally, however, virus replication in such cultures can be activated and then leads to the production of high concentrations of progeny virus in parallel to complete destruction of the cell sheet. It is under these circumstances only that a persistent infection of cell cultures with parvoviruses is finally recognized.

We have at present no detailed insight into the factors controlling, on the one side, the development and maintenance of persistent infection and, on the other side, confering latent infection into fulminant, frank virus replication. In primary and low-passage cell cultures established from latently infected tissues a virus-cell relationship could exist which might be described as "supraoptimal steady state infection." In such cultures the equilibrium between virus replication, virus-specific cytopathology, and cell proliferation is very delicate and may be controlled by two parameters. The first of these is assumed to consist in the percentage of cells infected in the original tissue. The second then concerns the number of cell doublings possible before density-dependent inhibition of cellular 
proliferation in the developing monolayer ensues. These two parameters could confine infection to a limited, but nevertheless increasing number of cells and, hence, would determine the time and the number of passages after which virus replication culminates in complete destruction of the cell sheet.

The virus/cell relationship in persistently infected, long-term passaged cell strains cannot be explained in the same way. As described by Lum (1970a), Hallauer et al. (1971), and by Bass and Hetrick (1978b), such cultures can continuously produce low concentrations of parvoviruses over a period of months or even years. In most cases, however, a sequence of alternating "virus positive" and "virus negative" passage cycles is observed. The terms "negative" and "positive" thereby refer to the detectability of infectious or hemagglutinating virus under the prevailing laboratory conditions. They do not imply complete absence of virussynthesizing cells. Unfortunately, cell cultures exhibiting such fluctuations in virus replication have not been examined by fluorescent antibody staining. For persistently infected cultures which continuously released RV over a period of 212 days, Bass and Hetrick (1978b), however, have shown that, at any given time, not more than $1-5 \%$ of the cells were engaged in virus synthesis.

It is not very likely that in long-term cultures the low percentage of susceptible cells is equivalent to the percentage of cells undergoing mitosis. If this were true, virus infection should sooner or later involve the whole monolayer. Similarly, it is difficult to ascribe the restriction of virus replication to a limited number of cells to the influence of antiviral factors in spite of the fact that at least RV is very sensitive to inhibition by interferon (Kilham et al., 1968). Rather, it may be hypothesized that, at any given time, only a limited percentage of cells of an otherwise virusresistent culture become susceptible to infection by derepression of certain genetic functions. Whether the result of this derepression consists in the appearance of specific receptors at the cell surface or whether distinct intracellular processes are turned on, remains to be shown. In any case, the frequency of the generation of susceptible cells at every passage level argues against mutational events playing an important role. Some observations of Hallauer et al. (1971) may be interpreted in favor of the above theory. These authors reported that an unrecognized latent infection can be activated if the cells are subjected to "stress" situations, such as incubation at the wrong temperature, by freeze-storing, or by addition of culture medium either lacking calf serum or having the wrong osmolarity.

At the level of the virus, persistent infection may also be the result of the presence of defective interfering (DI) particles or the generation of temperature-sensitive mutants. So far, these aspects of the parvoviruscell relationship have not been analyzed in detail. It is however, well known that autonomous as well as the helper-dependent parvoviruses readily give rise to the formation of incomplete and DI particles (Müller 
et al., 1978; Rhode, 1978; Carter et al., 1979; Siegl et al., unpublished) and that presence of this type of particles in the inoculum greatly affects the outcome of virus replication. On the other hand, ADV strains of low virulence apparently can be adapted to growth in CRFK cells only at temperatures in the range of $28^{\circ} \mathrm{C}$ (Porter and Cho, 1980). Under this condition persistent infections are readily established whereas the viruses apparently are lost from the cultures as soon as the temperature of incubation is shifted to $37^{\circ} \mathrm{C}$.

\section{E. Assay Systems}

Infectivity of the autonomous parvoviruses can be assayed in cell cultures by reading of unstained $\mathrm{CPE}$, by counting intranuclear inclusion bodies after histologic staining, by staining with fluorescent antibody, or on the basis of plaque formation. Each of these approaches has its advantages and disadvantages; all, however, yield suitable results only if the already repeatedly mentioned main prerequisite of parvovirus replication - the availability of cycling cells-is fulfilled. Even then unstained CPE may be weak, uncharacteristic, and transient in parallel with the disappearance of cycling cells as soon as the infected monolayer reaches confluence. In cultures inoculated at a low multiplicity of infection virus replication therefore frequently will pass undetected unless attempts are made to reactivate virus replication by repeated subculturing of the cell sheet. Moreover, extraction and assay of viral hemagglutinin may prove to be rewarding. Hallauer et al. (1972) have shown that by skillful combination of subcultivation and extraction of hemagglutinin up to three log higher infectivity titers can be recorded for one and the same virus suspension than are observed by reading of end points on the basis of virus-induced cytopathology.

It is obvious that titration of parvoviruses by this technique is laborious and time consuming. Moreover, the reliability of the results will depend on the patience of the investigator. This is also true for the assay of parvovirus infectivity by screening for specific intranuclear inclusions in stained monolayers. In this respect detection of one single characteristic inclusion is sufficient to prove the presence of infectious virus in the inoculum; yet, formation of inclusions was found to be time dependent (Johnson, 1965b, 1967a; Scott et al., 1970a,b). In consequence, multiple cultures of each dilution have to be screened at various times after infection to assure maximum sensitivity and reliability.

Under properly controlled experimental conditions staining of coverslip cultures by the direct or indirect fluorescent antibody technique probably provides the most feasible means to detect parvovirus infected cells. It is in general much easier to localize a single fluorescing cell against the background of an unstained monolayer than to discriminate a cell with more or less pronounced intranuclear changes from a mul- 
titude of only slightly different neighbors. Besides, fluorescent antibody staining is able to detect those early stages in the intranuclear accumulation of parvovirus antigen which do not show up by H\&E or MayGruenwald-Giemsa staining. On the basis of a comparable period of time allowed for screening of cultures the assay of parvovirus infectivity by the fluorescent antibody technique, therefore, can be of ten-fold to a hundredfold higher sensitivity than the reading of cytopathologic changes (Siegl and Kronauer, 1980). In addition, replication of ADV in CRFK cells can only be detected by this means. Hahn et al. $(1977 \mathrm{a}, \mathrm{b})$ have developed a fluorescent focus assay for this parvovirus which, under proper conditions, can be as effective as a plaque assay.

Plaque titration of parvovirus infectivity overcomes most of the problems associated with the methods listed in the previous paragraphs. In general, it yields the highest infectivity titers and, because its sensitivity is primarily not a function of the user's patience, it also yields the most reproducible results. So far, plaque tests have been developed for RV (Brailovsky, 1966), H-1 (Ledinko, 1967:, Rhode, 1973), MVM (Tattersall, 1972; Kajioka et al., 1974), BPV (Bates and Storz, 1973; Lubeck and Johnson, 1976), FPV (Siegl and Kronauer, 1980), and LuIII virus (Siegl and Kronauer, unpublished). The basis of each of these tests is a viable monolayer composed of cells which continue to proliferate under the overlay of the solidified medium. To meet this requirement, both viability and number of cells used to establish the monolayers as well as the time elapsing between seeding of cells and the inoculation of virus suspensions have to be carefully controlled. Moreover, solidification of the culture medium by addition of agar frequently is not suitable and electrophoresis grade agarose or methylcellulose have to be used to allow formation of plaques. There is some circumstantial evidence suggesting that unpurified agar and agarose contain some type of inhibitor(s) interfering with the spread of parvovirus from cell to cell. Substances active at the same level were also detected at a high frequency in fetal calf sera (Siegl and Kronauer, 1980; Tokuhisa et al., 1981). In consequence, pretesting of the ingredients of the overlay is an absolute necessity to guarantee reproducible results.

For most viruses plaque size and plaque morphology are assumed to reflect the genetic composition of the infecting particle. This is not necessarily true for parvoviruses. For the various members of this virus group it could be shown that the diameter of a plaque apparently is a function of the density of the infected monolayer rather than an expression of the virus genetic information. The use of plaque size as a genetic marker for parvovirus strains therefore should be treated with caution.

\section{PATHOGENESIS}

Parvoviruses have been frequently referred to as "viruses in search of a disease." This proved to be true especially in the early years following 
the discovery of these agents by Kilham and Olivier (1959) and by Toolan et al. (1960). At that time serologic surveys as well as the frequency of accidental isolations indicated that RV and $\mathrm{H}-1$ were wide spread in populations of both wild and laboratory rats and, yet, specific syndromes could only be observed after experimental infection of laboratory rodents. During the past two decades thorough studies have now related parvoviruses to a broad variety of syndromes developing both upon natural and upon experimental infection. These studies also shed some light on the conditions predisposing the course of parvovirus infection. In most instances, however, we are still far from being able to predict the course of events let alone to understand the interactions between viral and cellular function, the reaction of the organism, and the influence of adventitious environmental factors. It is hoped that, by presenting the pathogenic properties of parvoviruses in concise chapters, at least the outlines of some of the mechanisms active in parvovirus disease might show up.

\section{A. Natural and Experimental Host Range}

At first sight the results of various serological surveys and of transmission experiments suggest that parvoviruses can be divided into viruses easily crossing the species barrier and those replicating and inducing disease in their natural host species only. In fact, however, it is dangerous to make such a statement because the information available on the host range of individual members of the parvovirus group differs considerably with respect to both quantity and quality.

The most extended studies have been conducted with RV and antigenically related isolates. In accordance with the frequence of isolation of the viruses from rat tissues serologic surveys revealed antibodies in up to $85 \%$ of rat sera collected at various occasions (Moore and Nicastry, 1965; Kilham, 1966; Nathanson et al., 1968; Robey et al., 1968). Therefore, it appears to be safe to assume that the natural host of these viruses is the rat. Whereas, however, experimental injection of RV into neonates of the syrian hamster almost regularly resulted in the development of characteristic syndromes and frequently also in death of the animal (Kilham, 1961b), inoculation of RV into newborn rats usually led to inapparent infection rather than to acute lethal disease (Kilham, 1961a; Kilham and Moloney, 1964; Kilham and Margolis, 1966; El Dadah et al., 1967; Novotny and Hetrick, 1970). Due to pretesting of experimental animals in at least some of the studies, this failure to induce clinical disease in the most likely natural host cannot be attributed to the presence of anti-RV antibodies in the infected animals. Rather, genetic aspects of the infecting virus may play a significant role. In support of this view, Moore and Nicastri (1965) have observed that an initially apathogenic virus will gain in pathogenicity in the course of repeated successive an- 
imal-to-animal passages and, finally, may be able to cause acute lethal disease in newborn rats.

Without previous adaptation, however, RV was found to replicate and to induce disease in newborn mastomys (Rattus natalensis) (Rabson et al., 1961). Moreover, El Dadah et al. (1967) and Matsuo and Spencer (1969) recorded fatal paralysis and the development of acute lethal disease after intracerebral injection of the HER-virus and of RV, respectively, into less than day-old baby mice. Previous attempts to transmit RV to mice had failed (Kilham and Olivier, 1959; Lum and Schreiner, 1963). This failure very likely has been due to inappropriate experimental conditions because El Dadah et al. as well as Matsuo and Spencer could provide evidence that the route of infection (intracerebral instead of intraperitoneal) and the virus dose administered (at least $10^{4} \mathrm{TCID}_{50}$ ) were necessary prerequisites for successful induction of disease.

In contrast to the relatively clear situation with $\mathrm{RV}$, the designation of the main natural host of $\mathrm{H}-1, \mathrm{HT}$, and $\mathrm{HB}$ viruses is still controversal. These viruses were isolated from cell-free fractions of human tumors and other fast-growing human tissues by injection into hamster neonates (Toolan, 1961a, 1964, 1968; Toolan et al., 1961). Because thousands of uninfected hamsters tested by Toolan were seronegative for the viruses (Toolan, personal communication) and because blind passages of hamster tumors or tissues under identical conditions never yielded similar viruses, Toolan has concluded that man is the natural host of these viruses. Some additional support in favor of this view was derived from serological surveys which revealed antibodies to $\mathrm{H}-1$ virus in two out of 130 sera of woman with a history of abortions or congenital defects in their infants (Monif et al., 1965) and in "very few" of the 500 serum samples collected from cancer patients (Toolan, 1968). A considerably higher incidence of anti $\mathrm{H}-1$ positive sera $(13.71 \%)$ has recently been reported in a survey of 350 sera collected from woman with a history of repeated abortions and still birth (Guglielmino et al., 1978). 9.14\% of the same sera also contained $\mathrm{HI}$-antibodies to RV. The prevalence of antibodies to $\mathrm{H}-1$ and $\mathrm{RV}$ in 300 control samples collected from people in the same region but with no history of reproductive problems were 2.66 and $1.66 \%$, respectively. Finally, it has been repeatedly observed, that laboratory workers handling H-1 may develop high titer HI-antibody which can persist over years (Toolan, personal communication).

It is beyond question that $\mathrm{H}-1$ virus can proliferate in humans. This was shown by intramuscular injection of the virus into human volunteers (Toolan et al., 1965) as well as by direct isolation of the virus from both the tumor and the embryo of a pregnant woman with metastatic breast carcinoma (Toolan, 1964). The latter patient had developed HI-antibody to the virus at a titer of $1: 640$.

Data which are not in agreement with the above results and contradict the view taken by Toolan have been reported by Newman et al. (1970) and by Kilham and Margolis (1969). Newman et al. tried to isolate H-1 
or similar viruses from as many as 50 tissue specimens collected from cases of spontaneous human abortions by means of injection of tissue homogenates into newborn hamsters. In contrast to the frequency of isolates reported by Toolan (about $20 \%$ ) not a single virus could be recovered in these studies. Moreover, Kilham and Margolis (1969) isolated H-1 virus from tissues of rats and $\mathrm{HI}$-antibodies to the virus were detected in as many as $80 \%$ of sera collected from both wild and laboratory rats. The wild rats bled in the latter surveys had been caught in the surroundings of human garbage dumps near Hanover, New Hampshire.

At the present time, it is thus difficult if not impossible to decide whether man or rat or man and rat represent the natural reservoir for the $\mathrm{H}-1$ viruses. In any case, both species apparently are susceptible to natural and experimental infection. The idea that $\mathrm{H}-1$ virus infection has the characteristics of a zoonosis is tempting and might explain the differences in antibody prevalence and in frequency of isolations reported by the various investigators on a social and environmental basis. On the other hand, however, it is also conceivable that rats could have contracted infections by feeding on virus-contaminated human garbage.

On the basis of an increase in antibody titers it was also assumed that, after experimental injection, $\mathrm{H}-1$ virus can proliferate in newborn rhesus monkeys or in adult, tumor-bearing animals of this species (Toolan, 1966). Attempts to induce antibodies to RV, H-3, and HB-virus in monkeys were unsuccessful.

In respect to natural and experimental host range MVM, RTV, TVX, and perhaps also LuIII virus seem to be related to the "hamster osteolytic agents" RV and $\mathrm{H}-1$. Thus, according to the results of serologic surveys (Parker et al., 1970b), MVM is highly prevalent in colonies of wild and laboratory mice. Clinically apparent disease due to MVM infection, however, has not been observed in naturally infected animals. After experimental infection of susceptible baby mice nothing but a retardation in growth of the inoculated animals has been recorded (Kilham and Margolis, 1970). Low titer HI-antibody to MVM was also detected at a high incidence in sera of rats (Kilham and Margolis, 1970). The reliability of this finding has been questioned (Parker et al., 1970); yet, MVM apparently proliferates in various organs of newborn rats both after intraperitoneal and intracerebral injection. Clinical disease, however, is only observed after experimental injection of hamster neonates. In such animals the syndromes induced resemble those resulting from infection with RV and H-1 (Kilham and Margolis, 1970, 1971).

RTV, TVX, and LuIII virus have only been isolated from contaminated permanent cell lines (Hallauer et al., 1971) and no direct line to a potential natural host can be drawn. Screening of sera from many species for HI-antibody also yielded not the slightest indication in respect to the natural host of LuIII virus. For RTV and TVX, however, HI-antibodies were detected in 9/50 and 16/50 sera of laboratory rats, respectively (Siegl and Kronauer, unpublished), thus suggesting that the latter two viruses 
are at least able to proliferate in this rodent. Finally, RTV and LuIII virus were found to induce acute lethal disease after injection into day-old hamsters (Siegl, 1976; Soike et al., 1976). Soike et al. (1976) also could show that, after infection of pregnant hamsters, LuIII virus crossed the placenta and caused abortions at a high frequency.

The origin and natural hosts of parvoviruses like BPV, PPV, GPV, and LPV have been established beyond doubt. Numerous serological surveys provided evidence for the worldwide occurence of the viruses in populations of the respective natural host, i.e., in cattle, swine, and geese. Besides, BPV, PPV, and GPV are well known to cause characteristic syndromes in these animals both after natural and experimental infection (cf. Derzsy, 1967; Siegl, 1976; Storz and Leary, 1979; Matsunaga and Chino, 1981; Mengeling, 1981). Transmission to other animals has been attempted in some limited experiments only. Mayr et al. (1968), Cartwright et al. (1969), and Hallauer et al. (1971) reported that neither suckling mice and hamsters nor embryonated hen's eggs could be infected with PPV. GPV, on the other hand, replicated in embryonated eggs of geese, Muskovy ducks, and, after adaption by serial blind passages, also in embryonated eggs of white Peking ducks (Schettler, 1971b; Hoeckstra et al., 1977).

The minute virus of canines (MVC) was isolated from the feces of dogs and antibody to MVC was detected at an incidence of $70 \%$ in dog sera (Binn et al., 1970). The pathogenic potency of the virus as well as its experimental host range, however, are still unresolved.

Of the remaining two autonomous parvoviruses listed in Table IADV and FPV-Aleutian disease virus of mink apparently has a rather broad natural and experimental host range. Under natural conditions antibodies to ADV were found in sera of mink, ferrets, feral skunks, raccoons, and foxes (Ingram and Cho, 1974; Porter et al., 1980); yet, clinical disease was only observed to occur in mink and ferrets (Kenyon et al., 1966, 1967; Ohshima et al., 1978). After experimental infection of as many as 14 species of Mustelidae, Kenyon et al. (1978) detected antibodies in the mink, ferret, weasel, fisher, marten and striped skunk. In accordance with observations under field conditions, characteristic lesions were only present in experimentally infected mink and ferrets. Lesions observed in the striped skunk and in martens could not be unambiguously related to the injected virus.

The host range of feline parvovirus finally presents a complicated yet interesting problem. As described elsewhere in more detail (cf. Siegl, Chapter 9 of this volume), huge epidemics of "feline enteritis" have swept through Europe North America, and South America during the first decades of this century. The virus also has been shown to persist as endemic infection in feline populations all over the world (for references see Siegl, 1976). Up to the end of the 1930s, however, neither circumstantial nor experimental observations pointed to the existence of a susceptible species other than the cat (Urbain, 1933; Kikuth, et al., 1940; Syverton et 
al., 1943). It therefore aroused considerable interest when, beginning with 1947 in Canada (Shofield, 1949), an infectious agent indistinguishable from the virus incriminated in feline enteritis was found responsible for the outbreaks of severe enteritis in ranch mink. Subsequent studies revealed that the same or a very similar virus can proliferate and cause disease in raccoons and in coatimundi (Gorham et al., 1966; Johnson, 1967b; Nettles et al., 1980). The virus also could be transmitted to neonatal but not to adult ferrets (Schofield, 1949; Johnson, 1965; Johnson et al., 1967; Kilham et al., 1967).

In more recent years pandemics of enteritis have been observed in canines. All available evidence indicates that this highly contagious disease results from infection by CPV, a previously nonexisting host-range mutant of FPV. For example, antibody to FPV could not be found in canine sera collected before 1976 and it is still a matter of discussion whether FPLV or MEV can proliferate in dogs after experimental infection. Felines, however, are susceptible to infection with CPV (for references see Chapter 9).

The generation of host-range mutants of FPV which are able to spread and to cause disease in populations of a previously unaffected and, consequently, fully unsusceptible species necessarily raises the question for the factors predisposing the evolution of such viruses. At the present time there is at least some evidence that, in the case of CPV, handling of FPLV or MEV in the laboratory might have played a significant role (Johnson and Spradbrow, 1978; McMaster et al., 1981; Tratschin et al., 1982). If definite proof for this assumption can be obtained, experiments centered at the in vivo host range and the pathogenicity of parvoviruses will have to be conducted in the future under the strictest precautions only.

\section{B. Transmission}

As outlined in the previous sections, parvovirus infections are highly endemic in populations of their natural hosts. This observation points to the existence of a potent reservoir as well as to a very efficient mode of transmission of the viruses. With respect to reservoir there is reliable evidence that both infected animals succumbing to acute disease as well as those experiencing clinically inapparent infection shed the virus in their feces, in urine, saliva, and nasal secretions (Urbain, 1933; Lawrence et al., 1943; Schofield, 1949; Kenyon et al., 1963; Gorham et al., 1964; Derzsy, 1967; Eklund et al., 1968; Toolan, 1968; Parker et al., 1970b; Binn et al., 1970; Lipton et al., 1972; Storz and Leary, 1979; Mengeling, 1981). Information concerning the duration of shedding, however, is scarce. In the course of acute enteritis CPV has been recovered from the feces of dogs for only 10 days after the onset of disease (M.J.G. Appel, personal communication), and Johnson et al. (1976) also did not observe shedding of PPV beyond the interval of acute infection. The situation is 
different, however in the case of clinically inapparent infections (cf. Section IV.D). Circumstantial evidence suggests that persistently infected animals may harbor parvoviruses in the kidneys throughout their lives. In accordance with Kilham and Margolis (1966b) and Csiza et al. (1971c) such animals therefore can be suspected to shed the viruses into the environment by way of urine. Nothing is known about whether this shedding occurs in all infected animals at a constant low level, whether it takes place more or less periodically and is triggered by hormonal conditions, superinfections, and other unknown factors, or whether only some few individual excreters exist.

Due to their outstanding resistance to environmental factors such as temperature, $\mathrm{pH}$, detergents, and enzymes, excreted parvoviruses remain infectious over a prolonged period of time and constitute a continuous and frequently undetected source of infection. This has been recognized already in the early studies with FPLV where it proved almost impossible to protect susceptible control cats from contracting disease when kept in the usual animal quarters with infected animals (Hammon and Enders, 1939a, b; Kikuth et al., 1940; Lawrence et al., 1943). Similarly, susceptible weanling rats readily developed antibodies to RV when placed in clean cages in a rat colony room where this infection was endemic (Toolan, 1968; Robinson et al., 1971). The ability of PPV to survive under farm conditions was demonstrated by the seroconversion of pigs placed in a stable that had been routinely cleaned and then kept empty for 135 days after infected pigs were removed (Johnson et al., 1976). Finally, Pollock et al.(L.E. Carmichael, personal communication) could show that CPV survived in canine feces at room temperature for as long as 6 months. It may be concluded from all these observations that the main routes of transmission of parvoviruses are fecal-oral, saliva-aerosol-respiratory, or dust-respiratory. Besides, mechanical transport of the viruses via contaminated food (Lawrence et al., 1943), contaminated gloves (Larson, 1969, cited by Porter and Cho, 1980), or clothing (Carmichael and Binn, 1981) had been suspected to play a role in the spread from animal quarter to animal quarter as well as over long distances.

The isolation of PPV from semen and from testicles, as well as from scrotal lymph nodes of infected boars (Cartwright and Huck, 1967; Cartwright et al., 1969; McAdaragh and Anderson, 1975; Lucas et al., 1974) suggests that parvoviruses can also be sexually transmitted. However, vertical transmission by transplacental infection may be more important in the disemination of parvoviruses. This has been observed by Toolan et al. (1960) already in the early experimental studies with $\mathrm{H}-1$ virus. Since then this mode of transmission was reported for RV (Ferm and Kilham, 1964; Kilham and Ferm, 1964), LuIII (Soike et al., 1976), MVM (Kilham and Margolis, 1971), FPV (Kilham and Margolis, 1966; Kilham et al., 1967; Csiza et al., 1971), PPV (for reference see Mengeling et al., 1980; Mengeling, 1981), BPV (Storz et al., 1972; Inaba et al., 1973b; Storz et al., 1978b), as well as for ADV (Padgett et al., 1967; Porter et al., 1977a; 
Porter and Cho, 1980). Factors such as the time of gestation at which the animals acquire infection, their state of immunity, and last but not least, the genetic composition of the infecting virus apparently determine the outcome of in utero infection. The main prerequisite for transplacental infection, however, seems to be the presence of the virus in the blood stream independent of whether this is brought about by intraveneous injection of the virus or by viremia as result of the replication of virus in maternal tissues (Kilham and Margolis, 1969; Csiza et al., 1971a,b; Joo et al., 1976a; Mengeling and Cutlip, 1977; Storz et al., 1978b).

Several attempts have also been made to elucidate the transmission of parvoviruses at the level of ova. Kilham and Margolis (1968) observed that ova, whether mitotically inert or arrested in meiosis, were refractory to infection by RV. Vegetative cells of the ovary, however, apparently supported virus replication. In contrast, proliferation of MVM was reported to occur after in vitro infection of fertilized, two-cell mouse eggs deprived of their zona pellucida (Mohanty and Bachmann, 1974); yet, the development of the cultivated embryo was not affected. Under conditions where the zona pellucida was not removed, PPV did not penetrate into fertilized pig eggs (Wrathall and Mengeling, 1979a). The antigen remained associated with the zona pellucida and infectious virus could be transferred to seronegative gilts by transplantation of contaminated ova (Wrathall and Mengeling, 1979b). Early embronic loss and pregnancy failure then was assumed to result from infection of the uterine epithelium and, at later times, from infection and damage of the developing fetus. In context with the increasing importance of egg transplantations in animal live stock the potential risk of spreading parvovirus infections by this route therefore should be seriously considered.

Transmission of goose parvovirus via ova has also been reported by Derzsy (1967).

\section{The Spectrum of Disease}

\section{In Utero Infection, Fetal and Neonatal Death, and Congenital Malformations}

In their review of intrauterine and neonatal infections Kilham and Margolis (1975) have stated that the ability to induce transplacental infections is more widespread among parvoviruses than among any other group of viruses. In fact, the greater part of the spectrum of disease caused by these agents is related to intrauterine infection. It results either in death of the embryo and fetus, in obvious malformations, or in specific defects which sooner or later become evident during the animal's postnatal life. There is good evidence that the spectrum of syndromes reflects the state of histogenesis and organogenesis of the fetus at the time of infection. However, maternal and fetal immune response as well as hor- 
monal changes accompanying pregnancy also seem to modulate the effect of parvoviruses during in utero infection.

Direct in utero inoculation of fetuses as well as transplacental infection after injection of pregnant animals suggest that the embryos and fetuses of rats, hamsters, mice, cats, dogs, ferrets, pigs, and of cattle are susceptible to infection with the respective parvoviruses throughout the time of gestation (Toolan et al., 1960; Ferm and Kilham, 1963, 1964; Kilham et al., 1967, 1971; Kilham and Margolis, 1969, 1971; Joo et al., 1977; Storz et al., 1978b; Lenghaus et al., 1980; Mengeling, 198.1). The question whether parvoviruses also play a role in transplacental infections in man cannot be answered conclusively on the basis of the available data.

The reaction of the embryo and fetus to infection with parvoviruses varies considerably with the time of gestation. As already outlined in the section on transmission, the very early stages of the developing embryo apparently resist infection with parvoviruses. At what time this state of apparent insusceptibility is terminated has not been investigated to a reliable degree. In the hamster, implantation occurs around day six of gestation. It was reported that, up to that time, infection of pregnant animals with $\mathrm{H}-1, \mathrm{RV}$, and LuIII virus has no deleterious effect on the developing embryo (Ferm and Kilham, 1964, 1965; Soike et al., 1976; Toolan, 1978) Nevertheless, animals born to mothers infected during the preimplantation period may harbor the virus at the time of birth.

The hamster embryo seems to be most susceptible to infection by $\mathrm{H}-1$ and LuIII virus at around eight days or, in other words, at about the middle of the short gestation period of this species (Ferm and Kilham, 1964, 1965; Soike et al., 1976; Toolan, 1978). A high percentage of fetuses infected at that time die and are resorbed or aborted. Littermates surviving to parturition are frequently born severely ill and usually die shortly after birth. The effects of BPV and PPV on bovine and porcine embryos or fetuses, respectively, are quite similar. In both species the most severe consequences of in utero infection were recorded subsequent to infection in the first and second trimester of gestation. They consisted in death of the embryo or fetus, followed either by resorption, mummification, or abortion (Storz et al., 1978b; Joo et al., 1976a; Bachmann et al., 1975; Mengeling and Cutlip, 1977; Mengeling, 1981). In the pig mummified fetuses may be farrowed at term. Their presence in the uterus, however, can also prolong gestation and lead to stillbirth of apparently normal littermates (Narita et al., 1975). These immediate consequences of transplacental infection in the pig and a probably related, reduced neonatal vitality of affected litters are summarized under the term "reproductive failure." This syndrome is assumed to represent the major and usually only clinical response of pigs to infection with PPV.

Fetuses infected in the third trimester towards the end of gestation run a good chance of overcoming infection without obvious clinical manifestations. This has been observed after injection of the rodent parvo- 
viruses as well as of LuIII virus into pregnant rats and hamsters (Ferm and Kilham, 1964, 1965; Kilham and Margolis, 1966b; Soike et al., 1976). Toolan (1978), however, reported that injection of $\mathrm{H}-1$ virus into pregnant hamsters on days 12 to 14 of gestation, i.e., shortly before delivery, may cause as high a mortality and morbidity in the fetus and in newborns as does transplacental infection at midgestation. Because the progesterone levels in the gravid hamster closely parallel the observed bimodal mortality pattern, it was hypothesized that this hormone plays a distinct role in fetal mortality due to parvovirus infection. The most likely mode of action of the hormone was assumed to consist in its role as a T-cell suppressor, by means of which it could interfere with the development of an immunological response to the infecting agent. In this context it is also of interest that the resistance of the bovine and procine fetuses to infection with their specific parvoviruses late in gestation has been attributed to the beginning ability of the fetuses to generate an immune response (Redman et al., 1974; Bachmann et al., 1975; Cutlip and Mengeling, 1975; Storz et al., 1978b); The presence of antiviral antibody in considerable quantity and a continuously reduced ability of fetal tissues to support virus replication could be the reason for a limited proliferation and spread of the infecting agents. At the same time, however, restriction of virus replication in still differentiating tissues, partially inaccessible to antiviral antibody, could favor the development of distinctly located congenital malformations such as cerebellar hypoplasia (Kilham and Ferm, 1964; Kilham and Margolis, 1966a,b, 1971), hydrocephalus (Csiza et al., 1971), and perhaps also myocarditis (Lenghaus et al., 1980).

Neither the varying susceptibility of embryonal and fetal tissues nor the maternal and fetal immune response to the infecting parvovirus are sufficient criteria to explain the full and changing spectrum of disease resulting from in utero infection. As emphasized by Kilham and co-workers, genetically determined properties of the infecting virus are at least of similar importance. Thus, it was found (Ferm and Kilham, 1963) that a strain of RV which had been carried for 42 passages in neonatal hamsters readily crossed the placenta of pregnant rats. The virus was recovered from tissues of the uterus, the placenta, and the embryos of infected animals at significant titers. In contrast to the evident pathogenicity of this strain when injected directly into fetal rats or neonatal hamsters, however, none of the rat fetuses acquiring infection transplacentally showed any sign of clinical disease. Quite similar results were obtained with another strain of RV passaged many times in tissue culture (Kilham and Ferm, 1964). From these and further observations (Kilham and Margolis, 1969) it was concluded that the fewer laboratory passages a strain of $\mathrm{H}-1$ and RV has been subjected to, the more readily transplacental infections in hamsters and rats are accompanied by overt disease. In agreement with these observations Paul and Mengeling (1980) were recently able to select a strain of PPV for the production of a live virus vaccine which did not pass the placenta of pregnant gilts. However, the virus 
replicated in the tissues of the gilt as well as in the tissue of fetuses after direct in utero inoculation.

The results available to date allow no conclusion with respect to the nature of the virus-specific function(s) responsible for transplacental passage and in utero pathogenicity. No virus strain has been isolated so far which exhibited a specific affinity for a distinct type of embryonal or fetal tissue; rather, both embryos severely affected and those surviving in utero infection without clinical disease frequently were found to harbor the virus at comparable concentrations in a quite similar broad spectrum of tissues. Moreover, pathogenic as well as apathogenic strains caused viremia in pregnant animals and, as far as rodent parvoviruses are concerned, were able to pass the placenta. It is therefore quite unlikely that pathogenic strains are distinguished by an exceptional capability to proliferate and to spread in maternal and fetal tissues. On the other hand it has been repeatedly reported that the concentration of virus injected into pregnant hamsters or rats determines the severity of in utero disease. Injection of high concentrations of $\mathrm{H}-1$ virus into pregnant animals regularly resulted in death of embryos in utero or at birth. Inoculation of smaller quantities of the same virus, however, frequently induced distinct malformations or an overall deformation of the developing animal (Ferm and Kilham, 1964, 1965b; Toolan, 1978).

As regards the pathologic features of in utero disease, numerous macroscopic changes and microscopic lesions in the embroys and fetuses infected by the different parvoviruses have been recorded in great detail. Compilation of the vast information would exceed the scope of this review. In summary, however, it was observed that virus replication and the resulting lesions were most severe in tissues with the most pronounced cellular proliferation. In early gestation mesendermal tissues were heavily involved. With beginning differentiation the various organs represented the main goal of attack, and during late gestation the lamina propria and muscularis are preferentially affected. For detailed information on this subject the interested reader is referred to the reviews of Toolan (1968), Margolis and Kilham (1975), Siegl (1976), and Mengeling, (1981).

\section{The Osteolytic Syndrome}

Both after transplacental infection and after direct inoculation into newborn hamsters RV and related isolates, MVM, as well as the $\mathrm{H}$-viruses frequently give rise to the development of the so-called osteolytic syndrome. Affected animals develop either dwarfism and/or mongoloidlike features characterized by small flat face, microcephalic domed head, protruding eyes and tongue, missing or abnormal teeth, and fragile bones (Toolan, 1960; Dalldorf, 1960; Kilham, 1961b; Baer and Kilham, 1962a,b; Ferm and Kilham, 1965a; Baer and Kilham, 1965; Lipton and Johnson, 1972). Dwarfism as the result of parvovirus infection is also occasionally 
observed in litters of infected rats and mice (Moore, 1963; Moore and Nicastri, 1965; Matsuo and Spencer, 1969) and retardation in growth was reported to result from infection of calves with BPV, of piglets with PPV, and of goslings with GPV (Derzsy, 1967; Storz and Bates, 1973; Mengeling, 1981). Only in hamsters and rats, however, is the overall picture of dwarfism conserved throughout an animal's life, whereas affected mice, calves, piglets, and geese may overcome the difference in size to uninfected controls with progressive age.

The full spectrum of the osteolytic syndrome is most consistently observed in hamsters inoculated within $48 \mathrm{hr}$ after birth (Toolan, 1960). Inoculation after that time produces fewer malformations the older the animals are at the time of infection. This observation has been taken as indication of a restriction of parvovirus pathogenicity to proliferating and differentiating tissues. Moreover, the various facets of the osteolytic syndrome have greatly helped to formulate the hypothesis concerning the dependence of parvovirus replication on "dividing" cells (Margolis and Kilham, 1965). Finally, comparative studies with $\mathrm{H}-1$ virus and various strains of RV also suggested that, as is the case with transplacental infection, the genetic characteristics of the virus strain determine the spectrum and the severity of clinical disease in newborn rodents (Baer and Kilham, 1965; Ferm and Kilham, 1965a; Toolan, 1968).

As the term "osteolytic" already implies, the characteristic features of this syndrome can be related to the cytolytic attack of parvoviruses on osteogenic tissues (Ferm and Kilham, 1965b). Virus replication interferes with the growth of bones and teeth and, consequently, affects the development of the skeleton of infected hamsters. Dalldorf (1960), for example, observed virus-induced degeneration of osteoblasts at the growing costochondral junctions of long bones, and Ferm and Kilham (1965a) noticed severe effects of two strains of RV on the proper differentiation of the cranial sutures. The viruses used in the latter studies had a pronounced affinity for the membranous bones of the skull and the mandible. Interference of virus replication with the growth of the skull apparently leads to the characteristic microcephalic domed head of the "mongoloid" hamster with protruding eyes due to lack of skull space. Interestingly, however, the skeleton of infected animals in general is affected in all its parts and its proportionality usually is conserved.

The other facet of the osteolytic syndrome, i.e., the effect of rodent parvoviruses on the development of the denture of infected hamsters, has been thoroughly investigated in a series of studies by Baer and Kilham (1962a,b, 1964a,b, 1965, 1974) and by Cohen and Shklar (1964). In the main part of these experiments five-day-old suckling hamsters were infected with $\mathrm{H}-3$ virus and the development of lesions was recorded over a period of 18 months. Because the molar teeth of the suckling hamster develop on different days, the resulting abnormalities of individual teeth could be directly related to their stage of development at the time of infection. Within only $24 \mathrm{hr}$ after infection intranuclear inclusions were 
detected in cells of the most susceptible periodontal membrane. Virus replication then led to destruction of the membrane as well as of the supporting alveolar bone and, within 7 to 12 days after inoculation, resorption of roots and bony ankylosis could be observed. Shortened and deformed roots, resorption of roots and bones, as well as anomalous deposition of osteodentin and cementum were characteristic features of the teeth of the infected, grown-up hamster. Moreover, odontogenic tumors were detected within the body of the mandible and about the apical portion of the incisors in the maxilla in animals kept for 12 to 18 months after infection.

Inoculation of rodent parvoviruses into healthy adult hamsters and rats has never been reported to result in destruction of bones and teeth (Toolan, 1965) Engler et al. (1969) and Baer et al. (1971a), however, have shown that these viruses may interfere with the healing process of osseous wounds. Engler injected H-3 virus intravenously into an adult hamster one or three days after fracture of the forearm or after extraction of a maxillary second molar tooth. The virus replicated at the fracture site and replication apparently interfered with the formation of a fibrocartilagenous callus and subperiosteal osteogenesis along the diaphysis. It also caused retardation of osteogenesis in the alveoli. In this context it should be emphasized that replication of the virus in these regions cannot be attributed to a specific affinity of the virus for osteoblasts. Rather, the affinity of parvoviruses for cells undergoing mitosis triggers its accumulation at the fracture site. In consequence, the interference of parvoviruses with the healing of osseous wounds is just another aspect of the hazardous association of these agents with regenerating tissues (cf. Section IV.C.5).

The overall appearance of hamsters surviving the osteolytic attack of rodent parvoviruses has many features in common with the mongoloid phenotype of humans suffering from Down's syndrome. The similarities include the dental defects (Cohen et al., 1961), the conservation of an infantile skull with abnormal proportions (Baer et al., 1971b), as well as behavioral changes and reduced learning capacities (Landauer et al., 1967). Whereas the human deformities, however, are considered as being due to trisomy of chromosome 21 , no indication for a significant chromosomal anomaly could be found in the cells of deformed hamsters (Galton and Kilham, 1966). Moreover, in contrast to the genetic fixation of the syndrome in man, mongoloid animals gave birth to normal offspring (Toolan, 1960; Ferm and Kilham, 1965b). It has therefore been repeatedly speculated whether the physiologic conditions resulting from trisomy 21 might provide the medium for the cytolytic replication of one of the known or of an unknown parvovirus (Toolan, 1968; Kilham and Margolis, 1975). Neither serologic surveys nor isolation attempts, however, have furnished any reliable results in favor of this hypothesis (Monif et al., 1965; G. Siegl and G. Kronauer, unpublished). 


\section{Acute Lethal Disease in Newborn Animals}

Newborn animals are highly susceptible to generalized and often lethal infections with parvoviruses. This has been established in particular for the rodent parvoviruses. Infection of hamsters and rats with $\mathrm{H}-1, \mathrm{RTV}$, LuIII, and RV-type viruses shortly after birth usually terminated fatally within 5 to 14 days (Toolan, 1961b; Kilham, 1961a,b; Moore and Nicastri, 1965; Siegl, 1976; Soike et al., 1976). Clinical disease thereby consisted mostly in apathetic behavior, a sudden slugishness, and, occasionally, a tendency of the animals to gasp for breath. These symptoms usually became evident only some few hours before death ensued. At necropsy, macroscopic examinations frequently revealed a sanguineous exudate in the intestines, hemorrhages in the stomach and the kidneys, as well as congestion of the liver. Microscopic and virologic examinations, on the other hand, pointed to a systemic involvement of almost all organs and tissues in virus replication.

Generalized disease as a consequence of infection with parvoviruses has also been reported for FPLV in newborn kittens (Csiza et al., 1971a,b) and for CPV in a litter of puppies (Lenghaus et al., 1980). In cats and dogs, however, acute generalized disease in neonates seems to be the exception and more specific syndromes like enteritis, panleukopenia, and myocarditis apparently prevail. On the contrary, acute disease accompanied by a sometimes extraordinarily high incidence of mortality is characteristic for the infection of goslings with GPV (Kraus, 1965; Derzsy, 1967; Schettler, 1971a). In some outbreaks up to $95 \%$ of goslings between 1 and 30 days of age succumbed to infection. The course of clinical disease as well as the tissues preferentially involved in virus replication were found to vary with the age of the animals. Young animals between 4 and 8 days of age are most severely affected. They develop diarrhea, nasal catarrh, and incoordination of movements. After a rather short period of slugishness they may die within one to two days after the appearance of the first clinical signs. The most typical lesions found upon necropsy of animals dead after such a short episode of disease consisted of edema and diffuse degeneration of the myocardium as well as an exudative hepatitis (Derzsy, 1967; Kraus, 1965; Palya and Kisary, 1978; Schettler, 1971a). In older animals the liver, thyroids, and pancreas probably are the main target organs of viral attack. Animals older than two weeks at the time of infection have a good chance to survive (Coudart et al., 1974); yet, they may show retardation in growth for a certain period of time.

\section{Enteritis}

Enteritis is one of the most prominent features of parvovirus-induced disease. It frequently develops after infection of newborn animals but may also constitute a main syndrome after infection of adults. As outlined in the preceding section, newborn hamsters and rats inoculated with the 
rodent parvoviruses or with LuIII virus may show signs of hemorrhagic enteritis shortly before death. Moreover, diarrhea and vomiting are prominent clinical symptoms in feline enteritis (feline panleukopenia) (Urbain, 1933; Lawrence and Syverton, 1938; Lucas and Riser, 1945), in mink enteritis (Schofield, 1949; Wills, 1952; Myers et al., 1959; Reynolds, 1969), in canine parvovirus enteritis (Appel et al., 1978; Kelly, 1978; Robinson et al., 1980b), in goslings infected with GPV (Kraus, 1965; Derzsy, 1967), and in neonatal calves affected by BPV (Abinanti and Warfield, 1961; Storz et al., 1978a). Whether those viruses like MVC and LPV which have been recovered from the feces of apparently healthy dogs (Binn et al., 1970) and rabbits (Matsunaga et al., 1977), respectively, are also able to cause acute diarrhea, remains to be shown.

The enteric syndrome related to parvovirus infection represents an enigma. It is readily observed during epidemics and, thereby, may take an acute and drastic course. Discharge of watery, sometimes bloodstained stools can be accompanied by vomiting, pyrexia, anorexia, depression, and dehydration in varying extent. However, in all instances where naturally and experimentally infected animals were thoroughly examined both at the clinical and at the pathological level, diarrhea was found to be only one out of several and, in addition, the most inconsistent manifestation of disease. Nevertheless, the same studies have revealed that replication of the infecting virus always occurred in the cryptal epithelium of the small intestine (Csiza et al., 1971b; Robinson et al., 1980b; Storz et al., 1978a). Specific lesions were also observed in the cranial and mid-jejunum (Carlson et al., 1977), and, under extraordinary circumstances, the ileum and the colon of cats were found to be affected (Langheinrich and Nielsen, 1971; Larsen et al., 1976). In spite of the regular involvement of the intestinal tract in virus replication, attempts to reproduce the full spectrum of enteric disease under laboratory conditions have always met with difficulties (Bittle et al., 1961; O'Reilly, 1970; Carlson et al., 1977; Carlson and Scott, 1977; Robinson et al., 1980b). It was therefore concluded that circumstantial factors such as the physical condition of the animal at the time of infection, the presence of adventitious viruses, or coinfection with bacteria may be responsible for the induction of the enteric syndrome. Overt enteritis also was more frequently observed after infection of animals by the intraveneous and respiratory route than after oral exposure to the virus. Finally, there is evidence that feline parvovirus rapidly loses its enteropathogenicity during serial propagation in tissue culture (Carlson et al., 1977). Hence, freshly isolated or in vivo passaged virus strains seem to be necessary for experimental induction of disease.

\section{Hepatitis}

Involvement of the liver in parvovirus disease was first observed after spontaneous in utero infection of rat fetuses with RV (Kilham and Mar- 
golis, 1966a). Some of the offspring in such litters were jaundiced and large quantities of RV could be isolated from their livers. Subsequent studies indicated that severe hepatitis could be induced by inoculation of the virus into susceptible weanling rats and hamsters as late as 12 days postnatally (Margolis et al., 1968). At that age, the liver of rodents exhibits a considerable and continuing mitotic activity (Steiner et al., 1966) which apparently provides the medium for progressive replication of RV and the manifestation of disease in this tissue. Margolis et al. (1968) and Bergs and Scotti (1967) described the histopathologic changes resulting from replication of RV in the liver of neonatal rats as cryptic lesions of the parenchymal peliosis type.

The mitotic activity in the liver of rodents remains high for as long as 4-6 weeks after birth. Cessation of this activity then coincides with an apparent insusceptibility of the liver to parvovirus infection. Nevertheless, Henry and Diario (1975) have observed that $\mathrm{H}-1$ virus can induce hepatitis in adult, 4-6-month-old hamsters. No clinical symptoms could be recorded, but focal degeneration of hepatic cells as well as elevated liver enzymes were believed to be indicative of a continuing susceptibility of the differentiated liver to infection with parvoviruses. Because the liver has an extraordinary regenerative potential, susceptibility of the adult differentiated organ can be stimulated or even restored in the course of regeneration subsequent to hepatic injury. In this respect partial hepatectomy (Ruffalo et al.,1966), infection of rates with Cysticercus fasciolaris (the larval form of the feline tapeworm Taenia taeniaformis, Kilham Kilham et al., 1970), as well as carbon tetrachloride poisoning (Margolis and Kilham, 1975) were found to result in a vigorous reparative activity which provided the medium for massive replication of a simultaneously injected parvovirus.

Hepatitis is also one of the prominent manifestations of GPV infections in goslings. In the acute phase of disease the main pathologic lesions were reported to consist in an exudative hepatitis with serous parenchymal damage whereas at later stages subacute interstitial hepatitis developed (Palya and Kisary, 1978). In each stage replication of GPV in hepatocytes was indicated by the presence of Cowdry type A intranuclear inclusions.

\section{Myocarditis}

Post mortem examination of newborn animals dead from acute, generalized parvovirus infection revealed virus-specific intranuclear inclusion bodies in almost all tissues and also in the myocardium. Particularly widespread replication of parvoviruses in this tissue has been observed in newborn kittens infected with FPLV (Csiza et al., 1971a,b) and in calves infected with BPV (Storz and Leary, 1979). In none of these animals, however, was the involvement of the heart muscle in virus replication paralleled by a distinct clinical symptomatology. 
Lesions exceeding the mere presence of virus-infected cells in the myocardium are a consistent finding in goslings succumbing to infection with GPV. According to Derzsy (1967) the most typical changes are distension of the heart, rounding off of the cardiac apex, and diffuse degeneration of the myocardium. At later times the spectrum of lesions may be completed by reparative inflammation. Cowdry type A inclusion bodies were always present in the affected tissue. Such typical intranuclear inclusions in the myocardium also were the first indication for the involvement of a parvovirus in the etiology of the recently noticed acute epidemic heart failure in dogs. As has been shown by various investigators (cf. Hayes et al., 1979; Kelly and Atwell, 1979; Robinson et al., 1979a,b 1980a; Lenghaus et al., 1980|, this exceptional syndrome is caused by infection with CPV. However, myocarditis in dogs usually occurs without concurrent parvoviral enteritis. It is limited to puppies and, in general, onset and progression of clinical disease are rapid. Two clinical presentations have been described. Ths most common one in very young animals is characterized by sudden death occasionally preceded by a rather short period of dullness and dyspnoe. In dogs over eight weeks of age death frequently intervenes within $24 \mathrm{hr}$ after acute respiratory distress, depression, and weakness were observed. Survivers may develop congestive heart failure. According to the many detailed histologic examination of field cases (cf. Siegl, Chapter 9), the pathology of the disease presents as a marked interstitial myocarditis with loss of myofibers, multifocal myofiber necrosis, and mononuclear cell infiltrate. So far, attempts to reproduce myocarditis in dogs were successful only after in utero inoculation of puppies eight days before parturition (Lenghaus et al., 1980). Analysis of surviving animals in these studies also suggested that congestive heart disease in chronic myocarditis may be due to extensive focal fibrosis within the myocardium.

\section{Cerebellar Ataxia}

About a century ago, Herringham and Andrewes (1888) described the clinical and gross pathological features of cerebellar ataxia in kittens. Under field conditions usually the whole litter is affected and ataxic kittens in general show no other signs of disease. The syndrome therefore has been regarded as a congenital anomaly of genetic origin up to recent times. A first lead pointing to an infective etiology of this disease was obtained in the course of experiments with RV in newborn hamsters. After intracerebral injection of a specific strain of this parvovirus into baby hamsters less than four days of age (Kilham and Margolis, 1964), the typical clinical picture of ataxia became slowly evident after four to five weeks. The affected animals developed an unsteadiness in gait as well as an instability of balance. On sacrifice, it was noted that infection had resulted in severe hypoplasia of the cerebellum. Histologic examinations finally suggested this pathologic condition as being due to the 
selective attack of virus replication on the outer germinal layer of the differentiating cerebellum. Clinical ataxia and cerebellar hypoplasia were also observed subsequent to transplacental infection of rat fetuses with RV (Kilham and Margolis, 1966).

Attempts to induce ataxia in kittens by intracerebral injection of RV failed; yet, as was indicated by the appearance of intranuclear inclusion bodies and by partial destruction of the tissue, the virus was found to proliferate in the external germinal layer of the cerebellum of these animals (Kilham and Margolis, 1965). Clinical ataxia as well as the underlaying cerebellar hypoplasia finally could be reproduced by intracerebral inoculation of feline panleukopenia virus into newborn kittens (Kilham and Margolis, 1966; Johnson et al., 1967). Both in these kittens and in neonatal ferrets-which proved to be of exceptional value in the study of feline ataxia-histopathologic changes were indistinguishable from those observed in the ataxic hamster and rat. Characteristically, virus replication in the outer germinal layer led to the absence of a definitive granular cortex, and, sometimes, destruction of Purkinje cells could be observed.

Susceptibility of the cerebellum to parvovirus infection is limited to those developmental stages of the animals during which the differentiating outer germinal layer provides a maximum number of dividing, susceptible cells for virus replication. In the cat this stage is terminated at about nine days after birth. It may therefore be expected that, depending on the time of infection, infection with FPLV up to that age of the animal may induce lesions of verying severity. In fact, according to Csiza et al. (1971b) specific intranuclear fluorescence could be detected in the cerebellum, the cerebrum, and the spinal cord within three days after oral exposure or intranasal infection of newborn kittens. Virus replication subsequently resulted in a marked reduction of the cerebellar size. Clinical signs of ataxia, however, were absent in the animals. These observations plus additional experimental data (Kilham and Margolis, 1966a; Kilham et al., 1967; Duenwald et al., 1971), as well as circumstantial evidence suggest that most of the observed cases of spontaneous ataxia in kittens result from in utero infections.

Finally, very recent experiments with BPV seem to indicate that bovine fetuses exposed to the virus around 130 days of fetal development experience brain lesions resembling closely the findings with feline and rat parvoviruses. According to Storz (personal communication) they consisted of a depopulation of the germinative external granular cell layer of the cerebellum with granuloprival cortical atrophy.

\section{Hemorrhagic Encephalopathy}

After treatment of adult, apparently healthy rats with cyclophosphamide, El Dadah et al. (1967) recovered a strain of RV from the brain and spinal cord of animals exhibiting paralysis of the hind limbs. Intra- 
cerebral inoculation of this virus into suckling rats again resulted in acute fatal paralysis associated with hemorrhages and necrosis in the brain and spinal cord. This entity-hemorrhagic encephalopathy-could be subsequently reproduced with various strains of RV in newborn rats, mice, and hamsters (Nathanson et al., 1970; Cole et al., 1970; Margolis and Kilham, 1970, 1972). Although less common, it was also observed after infection of kittens and ferrets in utero or postnatally with FPLV. Margolis and Kilham $(1970,1975)$ have suggested that the basis of this disease is the attack of parvoviruses on the proliferating, supporting structure of the neonatal CNS. However, the contribution of various other factors to the development of the syndrome, such as, for example, the attack of the virus upon the pool of developing megacaryocytes also have to be considered (Margolis and Kilham, 1972).

\section{Panleukopenia}

Between 1938 and 1943 experimental work in several laboratories was centered on the clinicopathological features of feline infectious enteritis (Hammon and Enders, 1939a,b; Lawrence and Syverton, 1938; Kikuth et al., 1940; Lawrence et al., 1940, 1943). These studies revealed that, besides a more or less constant involvement of the intestine, a prominent characteristic of this devastating disease consisted in severe hematologic changes. In particular, a profound leukopenia was reported to occur. According to these investigations as well as to more recent comparative experiments in conventionally raised cats, in specific pathogen-free, and in germ-free animals leukopenia is the most constantly found facet of FPLV infection (Rohovsky and Fowler, 1971; Langheinrich and Nielsen, 1971; Larsen et al., 1976; Carlson and Scott, 1977; Carlson et al., 1978).

Characteristically, the fall in total white blood cell counts starts in parallel with the initial slow rise in temperature at about two to three days after infection. Lowest cell counts-as few as 100 leucocytes per $\mathrm{mm}^{3}$ have been reported in severe cases-are usually observed at the height of clinical disease. Recovery, on the other hand, is signaled by a detectable increase in leucocyte counts. Detailed studies have revealed that lymphocytes and neutrophiles are especially involved in the variation of the blood picture. There is also convincing evidence that the changes result from the primary and direct attack of FPLV upon the lymphoid tissues and the blood-forming organs. By three to four days after infection cytocidal replication of FPLV in lymphoid cells of the thymic cortex, in both follicular and paracortical areas of lymph nodes, as well as in the follicular and periarteriolar areas of the spleen can be observed. Virus specific inclusion bodies are also found in the bone marrow, and destruction of the primitive blood cells is believed to result in neutropenia.

Although not studied in such detail, hematologic changes comparable to those sketched in the preceding paragraph were also found to 
constitute a rather constant aspect of disease induced by the two other variants of FPV-MEV and CPV-in mink and dogs, respectively (Reynolds, 1969; Jacobs et al., 1980; Robinson et al., 1980b; Woods et al., 1980). Leukopenia resulting from infection with these viruses, however, in general is less pronounced, transient and, consequently, is frequently missed if no serial white blood cell counts are performed. Likewise, many pigs, irrespective of age, experience a transient, usually mild leukopenia within about the first ten days after initial exposure to PPV (Johnson and Collings, 1969, 1971; Mengeling and Cutlip, 1977; Joo et al., 1976a). Moreover, infection of lymphatic organs of calves by BPV also parallels the pathogenic events described for panleukopenia in newborn kittens (Storz et al., 1978a).

\section{The Impact of Parvoviruses on the Immune System}

It has been hypothesized that destruction by parvoviruses of cells responsible for the immune mechanism should have a considerable impact on the immunological responsiveness of the infected organism. Rather unexpectedly, first evidence for such an effect of parvovirus replication has come from in vitro studies. Bonnard et al. (1976) reported that filtered culture fluids of a subline of mouse EL-4 lymphoma inhibited the generation of cytolytic effect in allogenic mixed lymphocytic cultures. Immunosuppression could be attributed to a contaminating virus, a lymphotropic variant of MVM. In subsequent experiments this virus, but not the prototype strain of MVM, was shown to inhibit a variety of T-cell functions, e.g., antigen-induced proliferation, generation of cytolytic T-cell activity, and T-helper function. It did not, however, interfere with B-cell specific plaque-forming cell generation in vitro (McMaster et al., 1981; Engers et al., 1982). According to Bonnard et al. (1976), immunosuppressive effects can also be observed with RV in rat lymphocyte cultures.

As concerns the impact of parvovirus replication on the immunologic responsiveness of the infected organism, Schultz et al. (1976) showed that, in the course of feline panleukopenia, the lymphocyte responsiveness to phytohemagglutinin and to concanavalin A were depressed. Responses to B lymphocyte mitogens as well as antibody responses to rabbit red blood cells and to the infecting virus, however, were not impaired. In the course of clinically mild FPLV infections the humoral immune mechanisms may even be stimulated rather than inhibited (Carlson et al., 1978). In contrast to the latter observations, however, the immune responsiveness of mink suffering from Aleutian disease appears to be considerably reduced. Suppression of responsiveness to a variety of antigens thereby starts at about the time the infected animal develops the most outstanding feature of this syndrome, i.e., hypergammaglobulinemia (Porter et al., 1965, 1969; Kenyon, 1966; Lodmell et al., 1970; Trautwein et al., 1974). 


\section{Aleutian Disease of Mink}

Aleutian disease of mink is a rather complex entity which has several facets in common with disease induced by well-known and better understood parvoviruses; yet, it also includes a number of aspects resisting interpretation on the basis of today's knowledge. The most distinguishing features of $\mathrm{ADV}$ infection consist of a chronic, slowly progressive course and the involvement of immunological mechanisms in the production of lesions. The disease is characterized by widespread plasmacytosis, glomerulonephritis, arteritis, and focal hepatitis. Death may occur any time from 2 to 24 months after infection (Henson et al., 1966; Pan et al., 1970; Porter and Larsen, 1969; Drommer and Trautwein, 1975; Barcley, 1976; Porter and Cho, 1980).

Replication of ADV takes place after infection of fetal, newborn, and adult mink. It gives rise to chronic viremia; however, no disease seems to be caused by virus replication itself. It is assumed that the constant presence of huge amounts of viral antigen induces a maximal immune response as reflected by rapid proliferation of antibody-producing cells and the development of hypergammaglobulinemia. Porter (1981) has recently provided evidence that most of the gammaglobulin produced in the course of ADV infection is specific antiviral antibody. This antibody, however, is not capable of neutralizing viral infectivity and, hence, the circulating antigen-antibody complexes found in persistently infected mink are infectious.

The majority of lesions observed in the course of Aleutian disease are very likely mediated by deposition of immune complexes. Glomerular and arterial cell wall lesions were shown to contain deposits of IgG, C3, as well as of ADV antigen, and anti-ADV antibody could be eluted from affected kidneys (Henson et al., 1969; Porter et al., 1969, 1973). Moreover, immunosuppressive therapy can suppress the development of lesions (Cheema et al., 1972). Immunization of animals with a killed virus vaccine prior to challenge with live virus, on the other hand, increases drastically the severity of disease (Porter and Cho, 1980).

The severity and the spectrum of disease observed after infection of mink with ADV apparently is influenced by the ADV strain used, the host genotype, and the age at which the animal is infected. The relative contribution of these factors to the disease process has been discussed in detail by Porter and Cho (1980). This aspect is also referred to in Section IV. $\mathrm{F}$ of this review.

\section{Persistent, Clinically Inapparent Infection}

As indicated by the high incidence of antiviral antibodies, parvovirus infections are rather common in populations of their natural hosts. This observation suggests that for every virus a potent reservoir must exist 
from which infection of susceptible animals and reinfection of already immune animals takes place. It is not very likely that this reservoir consists exclusively in those animals experiencing acute clinical disease. With the exception of Aleutian disease of mink, the number of such animals in populations with endemic parvovirus infections is rather small. However, carriers shedding the virus in feces, urine, saliva, and seminal fluid over a long period of time after recovering from acute disease have been noticed. Csiza et al. (1971c), for example, reported that after in utero infection a kitten was found to disseminate FPLV in urine until it was sacrificed at 12 days of age. Other animals shed the virus in their feces for at least 43 days. Likewise, PPV could be recovered from the seminal fluid of pigs infected in utero and sacrificed at the age of 8 months (Johnson and Collings, 1971). Characteristically, such animals are found to have high titers of antibodies to the respective virus. A similar coexistence of antiviral humoral immunity and the presence of virus in the feces has also been reported to occur with RV, MVC, BPV, LPV, and GPV in apparently healthy hosts. In addition, almost all these parvoviruses were repeatedly recovered from kidneys, testicles, and lung tissue of such animals. There is sound evidence that the higher the titer of circulating antiviral antibody, the higher the probability of isolating infectious virus from an animal's tissue. It may be concluded, therefore, that persistent, clinically inapparent infection is the rule rather than the exception with parvoviruses.

The situation is different with ADV infections in mink and ferrets. Here, persistent infection is equivalent to acute clinical disease. In general it takes a progressive, fatal course. This is in particular true for mink of the Aleutian genotype. In non-Aleutian mink, however, up to one quarter of animals may develop a clinically inapparent, or nonprogressive type of ADV infection (Larsen and Porter, 1975; An and Ingram, 1977, 1978). Nevertheless, the animals contain low amounts of ADV in blood and tissues, and constant shedding of the virus seems to occur. Mink with inapparent infections therefore may constitute a continuing unrecognized source of virus for both horizontal and vertical transmission (An and Ingram, 1978).

We still do not know by which mechanisms the persistence of parvoviruses in the presence of a sometimes impressive immunity is maintained. Integration of the nucleic acid of autonomous parvoviruses into the genome of an infected cell has not been reported; yet, it seems to be possible that the virus can survive in contact-inhibited or chemically arrested, noncycling cells to the time this block for virus replication is released (Siegl and Kronauer, unpublished observation). In addition, direct cell-to-cell transfer of newly synthesized virus in tissue of low but continuing mitotic activity could perpetuate infection. Such reduced spread of virus may prevent the development of lesions and, at the same time would be barely accessible to the interruptive activity of humoral immunity. 
Because the presence of antibodies to parvoviruses seems to indicate a carrier state rather than to guarantee the absence of the virus, such immune animals may disseminate the virus if introduced into "clean" antibody-negative animal colonies. Moreover, persistent inapparent infections in "immune" animals could provide an explanation of the syndrome "reproductive failure" in pig herds. In this case, latent infection could be activated by the presentation to the virus of rapidly proliferating tissues as a consequence of pregnancy (Cartwright and Huck, 1967; Johnson and Collings, 1969; Mengeling, 1981). It is conceivable that a similar mechanism is responsible for the appearance of parvoviruses in tissues of healing wounds as well as for the repeatedly observed association of parvoviruses with tumors. In this context, derangement of the apparently delicate equilibrium between latent infection and the state of immunity by drugs or other treatment with immunosuppressive effect may play an additional role (El Dadah et al., 1967; Zhdanov and Merekalova, 1962; Payne et al., 1963; Lum and Schreiner, 1963).

\section{E. Parvovirus Infections and Cancer}

Much of the interest virologists have taken in parvoviruses at the time of their first isolation and identification around 1960 came from the frequent association of these agents with tumors. As has been already outlined in detail (cf. Introduction), the $\mathrm{H}$-viruses were discovered in the course of serial transplantation of human tumors in rodents (Toolan et al., 1960), RV and many of its isolates frequently appeared in rats bearing tumors or subjected to treatment with cancerogeneous agents (Kilham and Olivier, 1959; Zhdanov and Merekalova, 1962; Payne et al., 1963), and Hallauer et al. (1971) recovered parvoviruses at a high frequency from cell cultures derived from tumor tissues. This association of the virus with neoplastic tissues has led to speculations concerning their possible involvement in oncogenesis. In this respect, however, only negative evidence has been obtained (Kilham, 1966; Toolan, 1967a). Accumulation of parvoviruses in tumors can be explained on the basis of their affinity for dividing, constantly proliferating cells, and just contrary to the previously suspected role as oncogenic agents, they are now considered to harbor an antineoplastic potential.

Based on the known osteolytic activity of H-1, Toolan et al. (1965) injected the virus intramuscularly into two young patients who suffered from osteosarcoma, the rapid spread of which could not be influenced by conventional treatment. $\mathrm{H}-1$ virus proliferated readily in the patients and multiplication led to cyclic viremia. Unfortunately, however, virus replication proved to be without influence on the growth of the sarcoma. The "oncolytic" potential of parvoviruses has subsequently been studied in tumor-bearing hamsters and rats. Toolan (1967a) observed that hamsters infected soon after birth with $\mathrm{H}-1$ and $\mathrm{H}-3$ virus have an unusually 
low incidence of spontaneous tumors throughout their lives. Likewise, infection with parvoviruses interfered in a significant way with the induction of leukemias and solid tumors by Moloney leukemia virus and adenovirus 12, respectively (Toolan and Ledinko, 1968; Bergs, 1969). Additional and more detailed experiments are in progress. The respective preliminary results seem to conform to previous observations and indicate that, at least in hamsters, the "oncolytic" effect of $\mathrm{H}-1$ virus infections is demonstrable against the induction of tumors by adenovirus, Simian virus 40, and dimethylbenzanthrene (Soike, personal communication; Rhode, personal communication). It is quite conceivable that the reduced incidence of spontaneous or experimentally induced tumors in infected organisms results from the selective infection and rapid destruction of de novo transformed cells. Thereby, both latent and direct infection seem to excert the same effect of antineoplastic surveillance. Already developed and metastasing tumors, however, apparently provide an excellent medium for virus replication but cannot be removed before the immunologic response of the organism prevents further replication and spread of virus.

\section{F. Factors Influencing Pathogenicity}

In context with the presentation of the various aspects of disease resulting from infection with parvoviruses it proved continuously necessary to point to factors and conditions favoring or mitigating the course of clinicopathologic events. As more than twenty years of thorough experimental studies have shown, there is a series of such factors. Some control pathogenicity at the level of cellular susceptibility, some at the level of the infected organism, and epidemiologic conditions apparently control susceptibility of whole animal populations. The picture is completed by genetic variation of the infecting virus itself.

The dependence of the replication of autonomous parvoviruses on cells undergoing mitosis or, correctly speaking, on those passing actively through their division cycle, has been established beyond doubt. It is therefore quite understandable that parvovirus replication preferentially is observed in differentiating tissues and also in tissues which, though fully differentiated, have retained a high rate of cellular proliferation. Besides, replication of parvoviruses in general is cytocidal. In consequence, it is to be expected that fulminant replication is reflected by the generation of lesions in affected organs. Potent examples illustrating this relationship between cell proliferation, virus replication, and the development of disease are found in the embryo, the fetus, and in newborn animals (Margolis et al., 1971). Affinity of parvoviruses for "dividing" cells is also reflected by the accumulation of the agents in the callus of healing wounds as well as by their effect on lymphopoietic and hematopoietic tissues in the adult host. However, dependence of virus repli- 
cation on cycling cells explains only a small facet of parvovirus pathogenicity.

Generalized disease observed in various host species after infection of fetuses or neonates supports the view of Kilham and Margolis (1966b) that parvoviruses are pantropic. In spite of this fact and despite the presence of rapidly proliferating cells in almost every part of the immature organism, generalized, acute disease is a relatively rare event. Rather, both transplacental infections of fetuses and infection of neonates frequently culminate in distinct, well circumscribed syndromes such as cerebellar ataxia, myocarditis, and hepatitis. It is, however, quite unlikely, that, for instance, cerebellar ataxia or myocarditis ensues due to an unique susceptibility of the outer germinal layer of the immature cerebellum or of the differentiating myocardium to infection at the stage of development concerned. These tissues, however, lack the evident regenerative ability of, e.g., the liver. Therefore, it appears to be much more probable that the degree of definite differentiation at the time of infection determines the extent of virus-specific lesions and, hence, simulates a more or less pronounced pathogenic potential of the infecting virus. It should nevertheless be borne in mind that there is convincing experimental evidence for a developmentally controlled, cell-cycle-independent change in a cell's ability to support synthesis of a parvovirus (Tattersall, 1978b).

Another type of host "differentiation" interfering with the pathogenic potential of parvoviruses is illustrated by the ability of the bovine and porcine fetuses to muster a considerable immunologic response against viruses already during the third trimester of gestation. This capability apparently prevents systemic infection of fetuses as well as the induction of distinct lesions. Humoral immunity and differentiation-dependent susceptibility of cells and tissues finally may influence the picture of parvovirus pathogenicity at the level of the newborn and maturing animal. Serologic surveys have shown that parvoviruses in general are endemic in populations of their natural hosts. For example, HI-antibodies to $\mathrm{RV}$ were found in rat colonies at an incidence of more than $85 \%$ (Robey et al., 1968). In pigs and calves the respective figures are 78\% (Bachmann, 1969) and 86\% (Abinati and Warfield, 1961; Storz et al., 1972). This high prevalence of passive immunity will prevent infection of the offspring and thus, suppresses manifestation of disease characteristic for this developmental stage of the animal. The efficiency of this mechanism is well illustrated by the changing epidemiologic situation since the recent appearance of CPV in canine populations. The first rush of the virus in a then virgin, antiviral antibody-free canine population was accompanied by manifestation of the enteric form of disease in a high percentage of dogs of all ages. Similarly, the myocardial form was observed in an epidemic extent. Within the past two to three years, however, more than $60-80 \%$ of dogs in all parts of the world have developed antibodies to the virus (Walker et al., 1980; Carmichael and Binn, 1981). In parallel to this increase in herd immunity myocarditis has become a rare finding 
and enteric disease is only observed in puppies exposed to infection at the time maternally transmitted, passive immunity vanishes.

Canine parvovirus enteritis, feline panleukopenia, mink enteritis, and goose hepatitis also may serve to illustrate the importance of copathogens-viruses, bacteria, fungi, and parasites-in the course of parvovirus-induced disease. In every instance, field cases in general take a severe clinical course associated with the development of massive histopathologic lesions. Under controlled experimental conditions and, particularly, in specific pathogen-free or germ-free animals, however, the disease is usually rather mild. Signs of enteric disease are rarely observed; yet, virus replication can be demonstrated in almost all parts of the intestine (cf. Section IV.C.4).

Finally, pathogenicity of parvoviruses clearly is influenced by genetic factors of the infecting virus as well as by the genetic background of the infected host. As far as the virus is concerned, there are many experimental observations indicating that the spectrum of disease may change due to "adaptation" of a virus in the course of in vitro or in vivo passages. In vitro passages thereby tend to yield parvovirus strains of reduced pathogenicity (Kilham and Ferm, 1964; Kilham and Margolis, 1966b, 1969; Paul and Mengeling, 1980) whereas during in vivo passages the pathogenicity of the viruses in general is maintained or even enhanced (cf. Kilham and Margolis, 1966b; Toolan, 1968; Carlson et al., 1977). Moreover, recent comparison of the genomes of virus strains distinguished either by low pathogenicity - as in the case of FPLV vaccine viruses (Tratschin et al., 1982) - or by affinity for a distinct type of cell-as in the case of wild-type virus and the lymphotropic variant of MVM (McMaster et al., 1981; Tattersall, 1981; Ron and Tal, 1981)-have shown that such differences are paralleled by changes at the level of the viral genome. The viral functions affected by these changes and, hence, responsible for the variation in pathogenicity are widely unknown. It may be speculated that they control affinity of the virus for a certain type of cell, ability and efficiency of virus replication, or the type of virus particles (e.g., defective interfering particles) produced. If, for example, all these functions result in slow spread of the virus in the organism, its immunologic system of surveillance as well as the regenerative activity of the affected tissues may be able to keep virus-specific damage at a minimum.

Virus strains of greatly varying virulence have also been described for ADV (cf. Porter and Cho, 1980). In the case of this syndrome, however, the genetic background of the infected animal seems to play an extraordinary role with respect to the severity and course of clinical disease. Classic Aleutian disease was first described in mink homozygous for the recessive Aleutian coat color (Hartsough and Gorham, 1956). This genetic constellation apparently determines a lysosomal abnormality similar to that of the Chediak-Higashi syndrome. It was speculated that the same gene may increase susceptibility of mink to infection with ADV (Padgett et al., 1967; Johnson et al., 1975). Whether "susceptibility" in the sense 
used throughout this chapter in fact is responsible for the differences in disease observed in Aleutian-type and non-Aleutian-type mink remains to be shown. Nevertheless, mink with the said genetic background typically die of renal failure three or five months after infection. On the other hand, mink of non-Aleutian type rarely die earlier than five months after infection and most survive for more than one year (Porter and Cho, 1980).

In summary, the most evident factors controlling parvovirus pathogenicity are the genetic structure of the infecting virus, the genetic background of the infected host, the developmental stage of the host, the presence of viral, bacterial, fungal, or parasitic copathogens and, last but not least, the overall prevalence of the virus.

ACKNOWLEDGMENTS. I am greatly indebted to many colleagues who provided information and papers prior to publication. Thanks are also due to B. Thomson, who typed the manuscript.

\section{REFERENCES}

Abinanti, F.R., and Warfield, M.S., 1961, Recovery of a hemadsorbing virus (HADEN) from gastrointestinal tract of calves, Virology 14:288.

Al-Lami, F., Ledinko, N., and Toolan, H., 1969, Electron microscope study of human NB and SMH cells infected with the parvovirus $\mathrm{H}-1$ : Involvement of the nucleus, J. Gen. Virol. 5:485.

An, S.H., and Ingram, D.G., 1977, Detection of inapparent Aleutian disease virus infection in mink, Am. J. Vet. Res. 38:1619.

An, S.H., and Ingram, D.G., 1978, Transmission of Aleutian disease from mink with inapparent infections, Am. J. Vet. Res. 39:309.

Appel, M.J.G., Cooper, B.J., Greisen, H., and Carmichael, L.E., 1978, Status report: Canine viral enteritis, J. Am. Vet. Assoc. 173:1516.

Bachmann, P.A., 1969, Vorkommen und Verbreitung von Picodna (Parvo)-Virus beim Schwein, Zentralbl. Veterinaermed. Reihe B 16:341.

Bachmann, P.A., 1971, Properties of a bovine parvovirus, Zentralbl. Veterinaermed. Reihe B. 18:80.

Bachmann, P.A., and Danner, K., 1976, Porcine parvovirus infection in vitro: A study model for the replication of parvoviruses. II. Kinetics of virus and antigen production, Zentralbl. Veterinaermed. Reihe B. 23:355.

Bachmann, P.A., Sheffy, B.E., and Vaughan, J.T., 1975, Experimental in utero infection of fetal pigs with a porcine parvovirus, Infect. Immun. 12:455.

Baer, P.N., and Kilham, L., 1962a, Rat virus and peridontal disease. I. The peridontum in mongoloid hamsters, Oral Surg. Oral Med. Oral Pathol. 15:756.

Baer, P.N., and Kilham, L., 1962b, Rat virus and peridontal disease, II. Onset and effect of age and time of inoculation, Oral Surg. Oral Med. Oral Pathol. 15:1302.

Baer, P.N., and Kilham, L., 1964a, Rat virus and peridontal disease. III. The histopathology of early lesions in the first molar, Oral Surg. Oral Med. Oral Pathol. 17:116.

Baer, P.N., and Kilham, L., 1964b, Rat virus and periodontal disease. IV. The aged hamster, Oral Surg. Oral Med. Oral Pathol. 18:803.

Baer, P.N., and Kilham, L., 1965, A comparison of the effects of four viruses on the periodontium of the Syrian hamster, Periodontol. Res. 36:127. 
Baer, P.N., and Kilham, L., 1974, Dental defects in hamsters infected with minute virus of mice, Oral Surg. 37:385.

Baer, P.N., Garrington, G.E., and Kilham, L., 1971a, Effect of age and H-1 virus on healing fractures in hamsters, $J$. Geront. 26:373.

Baer, P.N., Coccaro, P.J., Baer, M:J., and Kilham, L., 1971b, Craniofacial manifestations of virus induced mongolism in the hamster and Down's syndrome in man, Am. J. Orthod. 60:221.

Bass, R., and Hetrick, F.M., 1978, Persistent infection of a human lymphocyte cell line (Molt-4) with the Kilham rat virus, J. Infect. Dis. 137:210.

Bates, R.C., and Storz, J., 1973, Host cell range and growth characteristics of bovine parvoviruses, Infect. Immun. 7:398.

Bates, R.C., and Storz, J., 1974, Morphogenesis of bovine parvoviruses and associated cellular changes, Exp. Mol. Pathol. 20:208.

Bates, R.C., Storz, J., and Reed, D.E., 1972, Isolation and comparison of bovine parvoviruses, J. Infect. Dis. 126:531.

Bazeley, P.O., 1976, The nature of Aleutian disease in mink. I. Two forms of hypergammaglobulinemia as related to method of disease transmission and type of lesion, $J$. Infect. Dis. 134:252.

Bergs, V.V., 1969, Rat virus-mediated suppression of leukemia induction by Moloney virus in rats, Cancer Res. 29:1669.

Bergs, V.V., and Scotti, T.M., 1967, Virus-induced peliosis hepatitis in rats, Science 128:377.

Bernhard, W., Kasten, F.H., and Chany, Th., 1963, Etude cytochimique et ultrastructurale de cellules infectées par le virus $\mathrm{K}$ du rat et le virus H-1, C.R. Acad. Sci. 257:1566.

Berquist, K.R., Maynard, J.E., Sheller, M., and Schable, C.A., 1972, Comparative studies of hepatitis candidate agents and parvovirus in Detroit 6 cell cultures, J. Infect. Dis. 126:203.

Binn, L.N., Lazar, E.C., Eddy, G.A., and Kajima, M., 1970, Recovery and characterization of a minute virus of canines, Infect. Immun. 1:503.

Bittle, J.L., Emery, J.B., York, C.J., and McMillen, J.K., 1961, Comparative study of feline cytopathogenic viruses and feline panleukopenia virus, Am. J. Vet. Res. 22:374.

Black, J.W., Holscher, M.A., and Povell, H.S., 1979, Parvoviral Enteritis and panleukopenia in dogs, Vet. Med. Sm. An. Clin. 74:47.

Bloom, M.E., Race, R.E., Hadlow, W.J., and Chesebro, R., 1975, Aleutian disease of mink: the antibody response of sapphire and pastel mink to Aleutian disease virus, I. Immunol. 115:1034.

Bloom, M.E., Race, R.E., and Wolfinbarger, J.B., 1980, Characterization of Aleutian disease virus as a parvovirus, J. Virol. 35:836.

Bonnard, G.D., Manders, E.K., Campbell, D.A., Herberman, R.B., and Collins, M.I., 1976, Immunosuppressive activity of a subline of the mouse EL-4 lymphoma. Evidence for minute virus of mice causing the inhibition, J. Exp. Med. 143:187.

Bouillant, A., and Hanson, R.P., 1965, Epizootiology of mink enteritis. III. Carrier state in mink, Can. J. Comp. Med. 29:183.

Brailowsky, C., and Chany, C., 1965, Un facteur produit par l'adenovirus 12 en culture cellulaire, stimulant la multiplication du virus $\mathrm{K}$ du rat, C.R. Acad. Sci. 260:2634.

Carlson, J.H., and Scott, F.W., 1977, Feline panleukopenia. II. The relationship of intestinal mucosal cell proliferation rates to viral infection and development of lesions, Vet. Pathol. 14:173.

Carlson, J.H., Scott, F.W., and Duncan, J.R., 1977, Feline panleukopenia. I. Pathogenesis in germfree and specific pathogen free cats, Vet. Pathol. 14:79.

Carlson, J.H., Scott, F.W., and Duncan, J.R., 1978, Feline panleukopenia. III. Development of lesions in lymphoid tissues, Vet. Pathol. 15:383.

Carmichael, L.E., and Binn, L.N., 1981, New enteric viruses in the dog, in: Advances in Veterinary Science and Comparative Medicine (C.E. Cornelius and C.F. Simpson, eds.), Vol. 25, p. 1-37, Academic Press, New York. 
Carmichael, L.E., Jaubert, J.C., and Pollock, R.V.H., 1980, Hemagglutination by canine parvovirus: Serologic studies and diagnostic applications, Am. J. Vet. Res. 41:784.

Carter, B.J., Laughlin, C.A., de la Maza, L.M., and Myers, M., 1979, Adeno-associated virus autointerference, Virology 92:449.

Cartwright, S.F., and Huck, R.A., 1967, Viruses isolated in association with herd infectivity, abortions and still births in pigs, Vet. Rec. 81:196.

Cartwright, S.F., Lucas, M., and Huck, R.A., 1969, A small hemagglutinating porcine DNA virus. I. Isolation and properties, J. Comp. Pathol. 79:371.

Castro, A., Cambria, M., and Russo, G., 1971a, Chemical characteristics of the erythrocyte receptors for picodnaviruses RV, H-1, and X 14, Boll. Ist. Sieroter. (Milan) 50:107.

Castro, A., Nicoletti, G., and Cocuzza, G., 1971b, Characteristics of hemagglutinins of the picodnaviruses (RV, H-1, X 14), Arch. Gesamte Virusforsch. 34:261.

Chany, C.H., and Brailovsky, C., 1965, Les stimulons, facteurs antagonistes de l'interféron favorisant la multiplication intracellulaire des virus, C.R. Acad. Sci. 261:4282.

Cheema, A., Henson, J.B., and Gorham, J.R., 1972, Aleutian disease of mink. Prevention of lesions by immunosuppression, Am. J. Pathol. 66:543.

Cho, H.J., and Ingram, D.G., 1972, Antigen and antibody in Aleutian disease in mink. I. Precipitation reaction by agar-gel electrophoresis, J. Immunol. 108:555.

Cho, H.J., and Ingram, D.G., 1973, Antigen and antibody in Aleutian disease in mink. II. The reaction of antibody with the Aleutian disease agent using immunodiffusion and immunoelectrophoresis, Can. J. Comp. Med. 37:217.

Clarke, D.H., and Casals, J., 1958, Techniques for hemagglutination and hemagglutinationinhibition with arthropod-borne viruses, Am. J. Trop. Med. Hyg. 7:561.

van Cleef, S.A.M., and Miltenburg, J.T., 1966, En erustige acuut verlopende virusziekte bij ganzekuikens gepaarde met grote sterfte, Tijdschr. Diergenesk. 91:6.

Clinton, M., and Hayashi, M., 1976, The parvovirus MVM: A comparison of heavy and light particle infectivity and their density conversion in vitro, Virology 74:57.

Cocuzza, G., and Russo, G., 1969, Erythrozyte receptors in hemagglutination by picodnaviruses, Boll. Ist. Sieroter. Milan. 48:204.

Cohen, M.M., and Shklar, G., 1964, Deformities of the cranofacial and dental complex in the H-1 virus modified hamster, Oral Surg., Oral Med. Oral Pathol. 17:533.

Cohen, M.M., Winer, R.A., Schwartz, S., and Shklar, G., 1961, Oral aspects of mongolism. Part I. Periodontal disease in mongolism, Oral Surg. 14:92.

Cole, G.A., and Nathanson, N., 1969, Immunofluorescent studies of the replication of rat virus (HER strain) in tissue culture, Acta Virol. 13:515.

Cole, G.A., Nathanson, N., and Rivet, H., 1970, Viral hemorrhagic encephalopathy of rats, II. Pathogenesis of central nervous system lesions, Am. J. Epidemiol. 91:339.

Cossart, Y.E., Field, A.M., Cant, B., and Widdows, D., 1975, Parvovirus like particles in human sera, Lancet I:72.

Coudert, M., Fedida, M., Dannacher, G., and Peillon, M., 1974, The late form of parvovirus disease of gosling, Rec. Med. Vet. 150:899.

Crawford, L.V., 1966, A minute virus of mice, Virology 29:605.

Croft, G.F., Hoggan, M.D., and Johnson, F.B., 1974, Production and reactivity of immune sera specific for HADEN virus polypeptide antigens, $J$. Virol. 13:608.

Croghan, D.L., Matchett, A., and Koski, T.A., 1973, Isolation of porcine parvovirus from commercial trypsin, Appl. Microbiol. 26:431.

Cross, S.S., and Parker, J.C., 1972, Some antigenic relationships of the murine parvoviruses: Minute virus of mice, rat virus and $\mathrm{H}-1$ virus, Proc. Soc. Exp. Biol. Med. 139:105.

Csiza, C.K., Scott, F.W., de Lahunta, A., and Gillespie, J.H., 1971a, Pathogenesis of feline panleukopenia virus in susceptible newborn kittens. I. Clinical signs, hematology, serology, and virology, Infect. Immun. 3:833.

Csiza, C.K., de Lahunta, A., Scott, F.W., and Gillespie, J.H., 1971b, Pathogenesis of feline panleukopenia virus in susceptible newborn kittens. II. Pathology and immunofluorescence, Infect. Immun. 3:838. 
Csiza, C.K., Scott, F.W., de Lahunta, A., and Gillespie, J.H., 1971c, Immune carrier state of feline panleukopenia virus-infected cats, Am. J. Vet. Res. 32:419.

Cutlip, R.C., and Mengeling, W.L., 1975, Pathogenesis of in utero infection of eight and ten-week-old porcine fetuses with porcine parvovirus, Am. J. Vet. Res. 36:1751.

Dalldorf, G., 1960, Viruses and human cancer, Bull. N.Y. Acad. Med. 36:795.

Dannacher, G., Fouillet, X., Coudert, M., Fedida, M., and Peillon, M., 1974, Etiologie de la maladie a virus de l'oison: le virus $\beta$. Rec. Med. Vet. 150:49.

Dawe, C.J., Kilham, L., and Morgan, W.D., 1961, Intranuclear inclusions in tissue cultures infected with rat virus, J. Natl. Cancer Inst. 27:221.

Derzsy, D., 1967, A viral disease of goslings. I. Epidemiological, clinical, pathological and aetiological studies, Acta Vet. Acad. Sci. Hung. 17:443.

Drommer, W., and Trautwein, G., 1975, Die Pathogenese der Aleutenkrankheit der Nerze. VII. Chronische Hepatitis mit Gallengangproliferation, Vet. Pathol. 12:77.

Duenwald, J.C., Holland, J.M., Gorham, J.R., and Ott, R.L., 1971, Feline panleukopenia: Experimental cerebellar hypoplasia produced in neonatal ferrets with live virus vaccine, Res. Vet. Sci. 12:394.

Eklund, C.M., Hadlow, W.J., Kennedy, R.C., Boyle, C.C., and Jackson, T.A., 1968, Aleutian disease of mink. Properties of the etiologic agent and the host responses, J. Infect. Dis. 118:510.

El Dadah, A.N., Nathanson, N., Smith, K.O., Squire, R.A., Santos, G.W., and Melby, E.C., 1967, Viral hemorrhagic encephalopathy of rats, Science 156:392.

Engers, H.D., Louis, J.A., Zubler, R.H., and Hirt, B., 1981, Inhibition of T-cell mediated functions by MVM (i), a parvovirus closely related to minute virus of mice, J. Immunol. 127:2280.

Engler, W.O., Baer, P.N., and Kilham, L., 1966, Effects of rat virus on healing osseous wounds, Arch. Pathol. 82:93.

Eugster, A.K., 1980, Studies of canine parvovirus infections: Development of an inactivated vaccine, Am. J. Vet. Res. 41:2020.

Ferm, V.H., and Kilham, L., 1963, Rat virus (RV) infection in fetal and pregnant hamsters, Proc. Soc. Exp. Biol. Med. 112:623.

Ferm, V.H., and Kilham, L., 1964, Congenital anomalies induced in hamster embryos with $\mathrm{H}-1$ virus, Science 145:510.

Ferm, V.H., and Kilham, L., 1965a, Skeletal studies of virus-induced dwarfism, Growth 29:7.

Ferm, V.H., and Kilham, L., 1965b, Histopathologic basis of the teratogenic effects of $\mathrm{H}-1$ virus on hamster embryos, J. Embryol. Exp. Morphol. 13:151.

Flower, R.L.P., Wilcox, G.E., and Robinson, W.F., 1980, Antigenic differences between canine parvovirus and feline panleucopenia virus, Vet Rec. 107:254.

Fowler, E.H., and Rohovsky, M.W., 1970, Enzyme histochemistry of the small intestine in germfree and specific-pathogen-free cats inoculated with feline infectious enteritis virus. Enzyme histochemistry of lymphoid tissues in germfree cats inoculated with feline enteritis, Am. J. Vet. Res. 31:2055.

Gagnon, A.N., and Povey, R.C., 1979, A possible parvovirus associated with an epidemic gastroenteritis of dogs in Canada, Vet. Rec. 104:263.

Galton, M., and Kilham, L., 1966, Chromosomes of "mongoloid" hamsters, Proc. Soc. Exp. Biol. Med. 122:18.

Gierthy, J.F., Ellem, K.A.O., and Singer, I.I., 1974, Environmental pH and the recovery of $\mathrm{H}-1$ parvovirus during single cycle infection, Virology 60:548.

Gorham, J.R., Leader, R.W., and Henson, J.B., 1964, The experimental transmission of a virus causing hypergammaglobulinemia in mink: Sources and modes of infection, $I$. Infect. Dis. 114:341.

Gorham, J.R., Hartsough, G.R., Sato, N., and Lust, S., 1966, Studies on cell culture adapted feline panleukopenia virus-virus neutralization and antigenic extinction, Vet. Med. 61:35.

Gorham, J.R., Leader, R.W., Crawford, T.B., and Padgett, G.A., 1976, The epizootiology of Aleutian disease, in: Slow Virus Diseases of Animals and Man (R.H. Kimberlin, ed.), pp. 135-158, North-Holland, Amsterdam. 
Goto, H., 1975, Feline panleukopenia in Japan. II. Hemagglutinability of the isolated virus, Ipn. J. Vet. Sci. 37:431.

Goto, H., and Ishiko, H., 1976, Feline panleukopenia in Japan. III. Propagation of the virus in cat kidney cell cultures, Jpn. J. Vet. Sci. 38:65.

Greene, E.L., 1964, Ph.D. thesis, Cornell University, Ithaca, N.Y.

Greene, E.L., 1965, Physical and chemical properties of H-1 virus. I. $\mathrm{pH}$ and heat stability of the hemagglutinating property, Proc. Soc. Exp. Biol. Med. 118:973.

Guglielmino, S., Tempera, G., Pappalardo, G., and Castro, A., 1978, H-1 and X14 parvovirus antibodies in women with abortions or still-births, Acta Virol. 22:426.

Hahn, E.C., Ramos, L., and Kenyon, A.J., 1977a, Expression of Aleutian mink disease antigen in cell culture, Infect. Immun. 15:204.

Hahn, E.C., Ramos, L., and Kenyon, A.J., 1977b, Properties of Aleutian disease virus assayed with feline kidney cells, Arch. Virol. 55:315.

Hallauer, C., and Kronauer, G., 1960, Nachweis von Gelbfieber virus-Hemagglutinin in menschlichen Explantaten, Arch. Gesamte Virusforsch. 10:267.

Hallauer, C., and Kronauer, G., 1962, Nachweis eines nicht identifizierten Hámagglutinins in meschlichen Tumorzellstämmen, Arch. Gesamte Virusforsch. 11:754.

Hallauer, C., and Kronauer, G., 1965, Extraction of cell-associated virus without damage of the culture, Arch. Gesamte Virusforsch. 15:433.

Hallauer, C., Kronauer, G., and Siegl, G., 1971, Parvoviruses as contaminants of permanent human cell lines. I. Virus isolations from 1960-1970, Arch. Gesamte Virusforsch. 35:80.

Hallauer, C., Siegl, G., and Kronauer, G., 1972, Parvoviruses as contaminants of permanent human cell lines. III. The biologic properties of the isolated viruses, Arch. Gesamte Virusforsch. 38:366.

Hammon, W.D., and Enders, J.F., 1939a, A virus disease of cats, principally characterized by aleucocytosis, enteric lesions and the presence of intranuclear inclusion bodies, $J$. Exp. Med. 69:327.

Hammon, W.D., and Enders, J.F., 1939b, Further studies on the blood and the hematopoietic tissues in malignant panleukopenia of cats, J. Exp. Med. 70:557.

Hampton, E.G., 1970, H-1 virus growth in synchronized rat embryo cells, Can. J. Microbiol. 16:266.

Hartsough, C.F., and Gorham, J.R., 1956, Aleutian disease of mink, Natl. Fur. News 28:10.

Hayes, M.A., Russell, R.G., and Babiuk, L.A., 1979, Sudden death in young dogs with myocarditis caused by parvovirus, J. Am. Vet. Med. Assoc. 174:1197.

Henry, C.J., and Diorio, A.F., 1975, Induction of hepatitis in adult Syrian hamsters by H1 virus, Proc. Soc. Exp. Biol. Med. 149:23.

Henson, J.B., Gorham, J.R., Leader, R.W., and Wagner, B.M., 1962, Experimental hypergammaglobulinemia in mink, J. Exp. Med. 116:357.

Henson, J.B., Leader, R.W., Gorham, J.R., and Padgett, G.A., 1966, The sequential development of lesions in spontaneous Aleutian disease of mink, Pathol. Vet. 3:289.

Henson, J.B., Gorham, J.R., and Padgett, G.A., 1969, Pathogenesis of the glomerular lesions in Aleutian disease of mink: Immunofluorescent studies, Arch. Pathol. 87:21.

Herringham, W.P., and Andrewes, F.W., 1888, Two cases of cerebellar disease in cats with staggering, St. Barth's Hosp. 24:112.

Hinaidy, B., Messner, A., and Bürki, F., 1979, Bovine Parvoviren-Isolierung in Zellkulturen, Zytopathologie und Kulturausbeute, Wien. Tieraerztl. Mschr. 66:359.

Hoekstra, J., Smit, Th., and van Brakel, C., 1973, Observations on host range and control of goose virus hepatitis, Avian Pathol. 2:169.

Horzinek, M., Mussgay, M., Maess, J., and Petzoldt, K., 1967, Nachweis dreier Virusarten (Schweinepest-, Adeno-, Picodna-Virus) in einem als cytopathogen bezeichneten Schweinepest-Virusstamm, Arch. Gesamte Virusforsch. 21:98.

Inaba, Y., Omori, T., Kono. M., Ishii, S., and Matumoto, M., 1973a, A new serotype of bovine parvovirus, Ipn, J. Microbiol. 17:85.

Inaba, Y., Kurogi, H., Takahashi, E., Sato, K., Tanaky, Y., Goto, Y., Omori, T., and Matumoto, M., 1973b, Isolation and properties of bovine parvovirus type I from Japanese calves, Arch. Gesamte Virusforsch. 42:54. 
Ingram, D.G., and Cho, H.J., 1974, Aleutian disease in mink: Virology, immunology and pathogenesis, J. Rheumatol. 1:74.

Jacobs, R., Weiser, M.G., Hall, R.L., and Kowalski, J.J., 1980, Clinicopathologic features of canine parvoviral enteritis, J. Am. Anim. Hosp. Assoc. 16:809.

Johnson, M.I., Henson, J.B., and Gorham, J.R., 1975, The influence of genotype on the development of glomerular lesions in mink with Aleutian disease virus. A correlated light, fluorescent, and electron microscopic study, Am. J. Pathol. 81:321.

Johnson, R.H., 1964, Isolation of a virus from a condition stimulating feline panleukopenia in a leopard, Vet. Rec. 76:1008.

Johnson, R.H., 1965a, Feline panleukopenia. I. Identification of a virus associated with the syndrome, Res. Vet. Sci. 6:466.

Johnson, R.H., 1965b, Feline panleukopenia virus. II. Some features of the cytopathic effects in feline kidney monolayers, Res. Vet. Sci. 6:472.

Johnson, R.H., 1967a, Feline panleukopenia virus. I.V. Methods for obtaining reproducible in vitro results, Res. Vet. Sci. 8:256.

Johnson, R.H., 1967b, Feline panleukopenia virus-In vitro comparison of strains with a mink enteritis virus, J. Small Anim. Pract. 8:319.

Johnson, R.H., and Collings, D.F., 1969, Experimental infection of piglets and pregnant gilts with a parvovirus, Vet. Rec. 85:446.

Johnson, R.H., and Collings, D.F., 1971, Tranplacental infection of piglets with a porcine parvovirus, Res. Vet. Sci. 12:570.

Johnson, R.H., and Cruickshank, J.G., 1966, Problems in classification of feline panleukopenia virus, Nature (London) 212:622.

Johnson, R.H., and Spradbrow, P.B., 1979, Isolation from dogs with severe enteritis of a parvovirus related to feline panleukopenia virus, Aust. Vet. J. 55:151.

Johnson, R.H., Margolis, G., and Kilham, L., 1967, Identity of feline ataxia virus with feline panleukopenia virus, Nature, (London) 214:175.

Johnson, R.H., Siegl, G., and Gautschi, M., 1974, Characteristics of feline panleukopenia virus strains enabling definitive classification as parvoviruses, Arch. Gesamte Virusforsch. 46:315.

Johnson, R.H., Donaldson-Wood, C.R., and Joo, H.J., 1976, Observations on the epidemiology of porcine parvovirus, Aust. Vet. J. 52:80.

Joo, H.S., Donaldson-Wood, C.R., and Johnson, R.H., 1975, A microneutralization test for the assay of porcine parvovirus antibody, Arch. Virol. 47:337.

Joo, H.S., Donaldson-Wood, C.R., and Johnson, R.H., 1976a, Observations on the pathogenesis of porcine parvovirus infection, Arch. Virol. 51:123.

Joo, H.S., Donaldson-Wood, C.R., and Johnson, R.H., 1976b, A standardised, haemagglutination inhibition test for porcine parvovirus antibody, Aust. Vet. J. 52:422.

Joo, H.S., Donaldson-Wood, C.R., Johnson, R.H., and Campbell, R.R.F., 1977, Pathogenesis of porcine parvovirus infection: Pathology and immunofluorescence in the fetus, $I$. Comp. Pathol. 87:383.

Joo, H.S., Johnson, R.H., and Watson, D.L., 1978, Serological procedures to determine time of infection of pigs with porcine parvovirus, Aust. Vet. J. 54:125.

Kääriäinen, L., Kangas, J., Keränen, S., Nyholm, M., and Weckström, P., 1966, Studies on mink enteritis virus, Arch. Gesamte Virusforsch. 19:197.

Kajioka, J., Taguchi, F., and Nagaki, D., 1974, Plaque formation and replication of minute virus of mice, Arch. Exp. Med. 47:33.

Karasaki, S., Toolan, H.W., and Usategui-Gomez, M., 1965, A human placental fluid inhibitor to hemagglutination by $\mathrm{H}-1$ and $\mathrm{HB}$-viruses. II. Electron microscopic studies, Proc. Soc. Exp. Biol. Med. 120:391.

Karstad, L., and Pridham, T.J., 1962, Aleutian disease of mink: Evidence of its viral etiology, Can. J. Comp. Med. 26:97.

Kelly, W.R., 1978, An enteric disease of dogs resembling feline panleukopenia, Aust. Vet. J. 54:593. 
Kelly, W.R., and Atwell, R.B., 1979, Diffuse subacute myocarditis of possible viral aetiology-A cause of sudden death in pups, Aust. Vet. J. 55:36.

Kenyon, A.J., 1966, Immunologic deficiency in Aleutian disease of mink, Am. J. Vet. Res. 27:1780.

Kenyon, A.J., Helmboldt, C.F., and Nielsen, S.W., 1963, Experimental transmission of Aleutian disease with urine, Am. J. Vet. Res. 24:1066.

Kenyon, A.J., Magnano, T., Helmboldt, C.F., and Buko, L., 1966, Aleutian disease in the ferret, J. Am. Vet. Med. Assoc. 149:920.

Kenyon, A.J., Howard, E., and Buko, L., 1967, Hypergammaglobulinemia in ferrets with lymphoproliferative lesions (Aleutian disease), Am. J. Vet. Res. 28:1167.

Kenyon, A.J., Kenyon, B.J., and Hahn, E.C., 1978, Protides of the mustelidae: Immunoresponse of mustelids to Aleutian mink disease virus, Am. J. Vet. Res. 39:1011.

Kikuth, W., Gönnert, R., and Schweickert, M., 1940, Infektiöse Aleukozytose der Katzen, Zentralbl. Bakt. I. Orig. 146:1.

Kilham, L., 1961a, Rat virus (RV) infections in hamsters, Proc. Soc. Exp. Biol. Med. 106:825.

Kilham, L., 1961b, Mongolism associated with rat virus (RV) infection in hamsters, Virology 13:141.

Kilham, L., 1966, Viruses of laboratory and wild rats, Natl. Cancer Inst. Monogr. 20:117.

Kilham, L., and Ferm, V.H., 1964, Rat virus (RV) infections of pregnant, fetal and newborn rats, Proc. Soc. Exp. Biol. Med. 117:874.

Kilham, L., and Margolis, G., 1964, Cerebellar ataxia in hamsters inoculated with rat virus, Science 143:1047.

Kilham, L., and Margolis, G., 1965, Cerebellar disease in cats induced by inoculation of rat virus, Science 148:244.

Kilham, L., and Margolis, G., 1966a, Viral etiology of spontaneous ataxia of cats, Am. J. Pathol. 48:991.

Kilham, L., and Margolis, G., 1966b, Spontaneous hepatitis and cerebellar hypoplasia in suckling rats due to congenital infection with rat virus, Am. J. Pathol. 49:457.

Kilham, L., and Margolis, G., 1969, Transplacental infection of rats and hamsters induced by oral and parenteral inoculations of $\mathrm{H}-1$ and rat viruses (RV), Teratology 2:111.

Kilham, L., and Margolis, G., 1970, Pathogenicity of minute virus of mice (MVM) for rats, mice, and hamsters, Proc. Soc. Exp. Biol. Med. 133:1447.

Kilham, L., and Margolis, G., 1971, Fetal infections of hamsters, rats and mice induced with the minute virus of mice (MVM), Teratology 4:43.

Kilham, L., and Margolis, G., 1970, Pathogenicity of minute virus of mice (MVM) for rats, mice, and hamsters, Proc. Soc. Exp. Biol. Med. 133:1447.

Kilham, L., and Margolis, G., 1971, Fetal infections of hamsters, rats and mice induced with the minute virus of mice (MVM), Teratology 4:43.

Kilham, L., and Margolis, G., 1975, Association of human concern arising from animal models of intrauterine and neonatal infections due to viruses: A review I. Introduction and virologic studies, Progr. Med. Virol. 20:113.

Kilham, L., and Molony, V.B., 1964, Association of rat virus and Moloney leukemia virus in tissues of inoculated rats, $J$. Natl. Cancer Inst. 32:523.

Kilham, L., and Olivier, L.J., 1959, A latent virus of rats isolated in tissue culture, Virology 7:428.

Kilham, L., Margolis, G., and Colby, E.D., 1967, Congenital infections of cats and ferrets by feline panleukopenia virus manifested by cerebellar hypoplasia, Lab. Invest. 17:465.

Kilham, L., Buchler, C.E., Ferm, V.H., and Baron, S., 1968, Production of interferon during rat virus infection, Proc. Soc. Exp. Biol. Med. 129:274.

Kilham, L., Margolis, G., and Colby, E.D., 1970, Enhanced proliferation of H-1 virus in livers of rats infected with Cysticercus fasciolaris, J. Infect. Dis. 121:648.

Kilham, L., Margolis, G., and Colby, E.D., 1971, Cerebellar Ataxia and its congenital transmission in cats by feline panleukopenia virus, J. Am. Vet. Med. Ass. 158:888.

King, D.A., and Crogham, D.L., 1965, Immunofluorescence of feline panleukopenia virus in cell culture: Determination of immunological status of felines by serum neutralization, Can. J. Comp. Med. 29:85. 
Kisary, J., 1974a, Cross-neutralization tests on parvoviruses isolated from goslings, Avian Pathol. 3:293.

Kisary, J., 1974b, Some growth characteristics of goose parvovirus strain B, Acta Vet. Acad. Sci. Hung. 24:329.

Kisary, J., 1979, Interaction in replication between the goose parvovirus strain B and duck plaque herpesvirus, Arch. Virol. 59:81.

Kisary, J., and Derzsy, D., 1974, A viral disease of goslings. IV. Characterization of the causal agent in tissue culture system, Acta Vet. Acad. Sci. Hung. 24:287.

Kongsvik, J.R., and Toolan, H.W., 1972a, Capsid components of the parvovirus H-1, Proc. Soc. Exp. Biol. Med. 139:1202.

Kongsvik, J.R., and Toolan, H.W., 1972b, Effect of proteolytic enzymes on the hemagglutinating property of the parvoviruses $\mathrm{H}-1, \mathrm{H}-3$, and RV, Proc. Soc. Exp. Biol. Med. 140:140.

Kongsvik, J.R., Singer, I.I., and Toolan, H.W., 1974, Studies on the red cell and antibody reactive sites of the parvovirus H-1: effect of fixatives, Proc. Soc. Exp. Biol. Med. 145:763.

Kongsvik, J.R., Hopkins, M.S., and Ellem, K.A.O., 1978, Two populations of infectious virus produced during $\mathrm{H}-1$ infection of synchronized transformed cells, in: Replication of Mammalian Parvoviruses (D.C. Ward and P. Tattersall, eds.), pp. 505-520, Cold Spring Harbor Laboratory, Cold Spring Harbor, New York.

Konishi, S., Mochizuki, M., and Ogata, M., 1975, Studies on feline panleukopenia. I. Isolation and properties of virus strains, Ipn. J. Vet. Sci. 37:439.

Krauss, H., 1965, Eine verlustreiche Aufzuchtkrankheit bei Gänseküken (Erste Mitteilung), Berl. Meunch. Tieraerztl. Wochenschr. 78:372.

Landauer, K., Kilham, L., and Buchtel, H.A., 1967, Behavioral characteristics associated with the rat-virus-induced "hamster mongolism" syndrome, J. Psychiat. Res. 5:95.

Langheinrich, K.A., and Nielsen, S.W., 1971, Histopathology of feline panleukopenia: Report of 65 cases, J. Am. Vet. Med. Assoc. 158:863.

Larsen, A.E., and Porter, D.D., 1975, Pathogenesis of Aleutian disease in mink: Identification of non-persistent infections, Infect. Immun. 11:92.

Larsen, S.A., Flagstad, A., and Aalbaek, B., 1976, Experimental feline panleukopenia in the conventional cat, Vet. Pathol. 13:216.

Lawrence, J.S., and Syverton, J.T., 1938, Spontaneous agranulocytosis in the cat, Proc. Soc. Exp. Biol. Med. 38:914.

Lawrence, J.S., Syverton, J.T., Shaw, J.S. Jr., and Smith, F.P., 1940, Infectious feline agranulocytosis, Am. J. Pathol. 16:333.

Lawrence, J.S., Syverton, J.T., Ackart, R.J., Adams, W.S., Ervin, D.M., Haskins, A.L., Jr., Sounders, R.H., Jr., Stringfellow, M.B., and Wetrick, R.M., 1943, The viruses of infectious feline agranulocytosis. II. Immunological relations to other viruses, I. Exp. Med. 77:57.

Leary, J.J., and Storz, J., 1980, Nucleopathic changes in parvovirus-infected, cultured cells, Exp. Mol. Pathol. 32:188.

Ledinko, N., 1967, Plaque assay of the effects of cytosine arabinoside and 5-iodo-deoxiuridine on the synthesis of $\mathrm{H}-1$ virus particles, Nature (London) 214:1346.

Ledinko, N., and Toolan, H.W., 1968, Human adenovirus type 12 as a "helper" for growth of $\mathrm{H}-1$ virus, $J$. Virol. 2:155.

Ledinko, N., Hopkins, S., and Toolan, H., 1969, Relationship between potentiation of H-1 growth by human adenovirus 12 and inhibition of the "helper" adenovirus by $\mathrm{H}-1, J$. Gen. Virol. 5:19.

Lenghaus, C., and Studdert, M.J., 1980, Relationships of canine panleukopenia (enteritis) and myocarditis parvoviruses to feline panleukopenia virus, Aust. Vet. J. 56:152.

Lenghaus, M.J., Studdert, M.J., and Finnie, J.W., 1980, Acute and chronic canine parvovirus myocarditis following intrauterine inoculation, Aust. Vet. J. 56:465.

Lipton, H.L., and Johnson, R.T., 1972, The pathogenesis of rat virus infections in the newborn hamster, Lab. Invest. 27:508. 
Lipton, H., Nathanson, N., and Hodous, J., 1972, Enteric transmission of parvoviruses: Pathogenesis of rat virus infection in adult rats, Am. J. Epidemiol. 96:443.

Lodmell, D.L., Hadlow, W.J., Munoz, J.J., and Whitford, H.W., 1970, Hemagglutinin antibody response of normal and Aleutian disease-affected mink to key hole limpet hemocyanin, J. Immunol. 104:878.

Lubeck, M.D., and Johnson, F.B., 1976, Multiplication of bovine parvovirus in two cell strains, Infec. Immunity 13:1289.

Lucas, A.M., and Riser, W.H., 1945, Intranuclear inclusions in panleucopenia of cats. A correlation with the pathogenesis of the disease and comparison with inclusions of herpes, B-virus, yellow-fever, and burns, Am. J. Pathol. 21:435.

Lucas, M.H., Cartwright, S.F., and Wrathall, A.E., 1974, Genital infection of pigs with porcine parvovirus, J. Comp. Pathol. 84:347.

Lum, G.S., 1970a, In-vitro studies of rat viruses. I. Effects of long-term culture, Oncology 24:401.

Lum, G.S., 1970b, In-vitro studies of rat viruses. II. Effects of heat, X-irradiation and carcinogenic drugs, Oncology 24:416.

Lum, G.S., 1970c, Serological studies of rat viruses in relation to tumors, Oncology 24:335.

Lum, G.S., and Schreiner, A.W., 1963, Study of a virus isolated from a chloroleukemic Wistar rat, Cancer Res. 23:1742.

Majaniemi, I., Tratschin, J.D., and Siegl, G., 1981, A reassessment of the nucleic acid and protein components of parvovirus LuIII, Proceedings 5th International Congress Virology, Strasbourg, p. 366.

Margolis, G., and Kilham, L., 1965, Rat virus, an agent with an affinity for the dividing cell, in: Slow, Latent and Temperate Virus Infections (D.C. Gajdusek, C.J. Gibbs, and M. Alpers, eds.), pp 361-367, NINDB Monograph No. 2, U.S. Government Printing Office, Washington, D.C.

Margolis, G., and Kilham, L., 1970, Parvovirus infections, vascular endothelium, and hemorrhagic encephalopathy, Lab. Invest. 22:478.

Margolis, G., and Kilham, L., 1972, Rat virus infection of megakariocytes: A factor in hemorrhagic encephalopathy? Exp. Mol. Pathol. 16:326.

Margolis, G., and Kilham, L., 1975, Problems of human concern arising from animal models of intrauterine and neonatal infections due to viruses: A review. II. Pathologic studies, Progr. Med. Virol. 20:144.

Margolis, G., Kilham, L., and Ruffolo, P.R., 1968, Rat virus disease, an experimental model of neonatal hepatitis, Exp. Mol. Pathol. 8:1.

Margolis, G., Kilham, L., and Johnson, R.H., 1971, The parvoviruses and replicating cells: Insights into the pathogenesis of cerebellar hypoplasia, Progr. Neuropathol. 1:168.

Matsunaga, Y., and Chino, F., 1981, Experimental infection of young rabbits with rabbit parvovirus, Arch. Virol. 68:257.

Matsunaga, Y., Matsuno, S., and Mukoyama, J., 1977, Isolation and characterization of a parvovirus of rabbits, Infect. Immunity 18:495.

Matsuo, Y., and Spencer, H.J., 1969, Studies on the infectivity of rat virus (RV) in BALB/c mice, Proc. Soc. Exp. Biol. Med. 130:294.

Mayor, H.D., and Ito, M., 1968, The early detection of picodnavirus X14 by immunofluorescence, Proc. Soc. Exp. Biol. Med. 129:684.

Mayor, H.D., and Jordan, E.L., 1966, Electron microscopic study of the rodent "Picodnavirus" X14, Exp. Mol. Pathol. 5:580.

Mayr, A. Bachmann, P.A., Siegl, G., Mahnel, H., and Sheffy, B.E., 1968, Characterization of a small porcine DNA virus, Arch. Gesamte Virusforsch. 25:38.

McAdaragh, J.P., and Anderson, G.A., 1975, Transmission of viruses through boar semen, Proc. 18th Am. Assoc. Vet. Lab. Diag. pp. 69-76.

McMaster, G.K., Beard, P., Engers, H.D., and Hirt, B., 1981a, Characterization of an immunosuppressive parvovirus related to the minute virus of mice, J. Virol. 38:317.

McMaster, G.K., Tratschin, J.D., and Siegl, G., 1981b, Comparison of canine parvovirus with mink enteritis virus by restriction site mapping, J. Virol. 38:368. 
McPherson, J.W., 1956, Feline enteritis virus-Its transmission to mink under natural and experimental conditions, Can. J. Comp. Med. 20:197.

Melnick, J.L., Boucher, D.W., Clarke, J., and Boggs, J., 1971, Properties of a virus isolated from patients with MS-1 infectious hepatitis, J. Infect. Dis. 124:76.

Mengeling, W.L., 1972, Porcine parvovirus: Properties and prevalence of a strain isolated in the United States, Am. J. Vet. Res. 33:2239.

Mengeling, W.L., 1975, Porcine parvovirus: Frequency of naturally occuring transplacental infection and viral contamination of fetal porcine kidney cell cultures, Am. J. Vet. Res. 36:41.

Mengeling, W.L., 1981, Porcine parvovirus infection, in: Diseases of Swine (A.D. Leman, ed.), pp. 352-365, Iowa State Press, Ames, Iowa.

Mengeling, W.L., and Cutlip, R.C., 1977, Reproductive disease experimentally induced by exposing pregnant gilts to porcine parvovirus, Am. J. Vet. Res. 37:1393.

Mengeling, W.L., Cutlip, R.C., Wilson, R.A., and Parks, J.B., 1975, Fetal mumification associated with porcine parvovirus infection, J. Am. Vet. Med. Assoc. 166:993.

Mengeling, W.L., Paul, P.S., and Brown, T.T., 1980, Transplacental infection and embryonic death following maternal exposure to porcine parvovirus near the time of conception, Arch. Virol. 65:55.

Mirkovic, R.R., Adamova, V., Boucher, D.W., and Melnick, J.L., 1971, Identification of the Kirk hepatitis virus as a member of the parvovirus (picodnavirus) group, Proc. Soc. Exp. Biol. Med. 138:626.

Mochizuki, M., Konishi, S., and Ogata, M., 1978, Studies on feline panleukopenia. II. Antigenicities of the virus, Ipn. J. Vet. Sci. 40:375.

Mohanty, S.B., and Bachmann, P.A., 1974, Susceptibility of fertilized mouse eggs to minute virus of mice, Infect. Immunity 9:762.

Monif, G.R.G., Sever, J.L., and Cochran, W.D., 1965, The H-1 and the RV viruses and pregnancy: Serological study of certain groups of pregnant women, J. Pediatrics 67:253.

Moore, A.E., 1962a, Characteristics of certain viruses isolated from transplantable tumors, Virology 18:182.

Moore, A.E., 1962b, Relationship between H-1, H-3, and RV viruses, Proc. Am. Assoc. Cancer. Res. 3:345.

Moore, A.E., 1963, Fatal infection of $\mathrm{A} \times \mathrm{C}$ rats with $\mathrm{H}$-viruses, Proc. Am. Assoc. Cancer Res. 4:45.

Moore, A.E., and Nicastri, A.D., 1965, Lethal infection and pathological findings in A $\times$ C rats inoculated with H-virus and RV, I. Natl. Cancer Inst. 35:937.

Müller, H.P., Gautschi, M., and Siegl, G., 1978, Defective particles of parvovirus LuIII, in: Replication of Mammalian Parvoviruses (D.C. Ward and P. Tattersall, eds.), pp. 231240, Cold Spring Harbor Laboratory, Cold Spring Harbor, New York.

Myers, W.L., Alberts, J.O., and Brandly, C.A., 1959, Certain characteristics of the virus of infectious enteritis of mink and observations on pathogenesis of the disease-Preliminary report, Can. J. Comp. Med. 23:283.

Narita, M., Inui, S., Kawakami, Y., Kitamura, K., and Maeda, A., 1975, Histopathological changes of the brain in swine fetuses naturally infected with porcine parvovirus, Natl. Inst. Anim. Health Qt. 15:24.

Nathanson, N., Cole, G.A., Santos, G.W., Squire, R.A., and Smith, K.O., 1970, Viral hemorrhagic encephalopathy of rats. I. Isolation, identification, and properties of the HER strains of rat virus, Am. J. Epidemiol. 91:328.

Newman, S.J., McCallin, P.F., and Sever, J.L., 1970, Attempts to isolatc H-1 virus from spontaneous human abortions: A negative report, Teratology 3:279.

Nettles, V.F., Pearson, J.E., Gustafson, G.A., and Blue, J.L., 1980, Parvovirus infection in translocated raccoons, J. Am. Vet. Med. Assoc. 177:787.

Nettleton, P.F., and Rweyemamu, M.M., 1980, The association of calf serum with the contamination of BHK 21 clone 13 suspension cells by a parvovirus serologically related to the minute virus of mice, Arch. Virol. 64:359. 
Nicoletti, G., Castro, A., Russo, G., and Cocuzza, G., 1969, Citopatologia da picodnavirus (RV, H-1, X14) in cellule di embrione di ratto, Ann. Sclavo 11:188.

Notani, G.W., Hahn, E.C., Sarkar, N.H., and Kenyon, A.J., 1976, Characterization of Aleutian disease antigens, Nature (London) 261:56.

Novotny, J.F., and Hetrick, F.M., 1970, Pathogenesis and transmission of Kilham rat virus infection in rats, Infect. Immunity 2:298.

O'Reilly, K.J., and Whitaker, A.M., 1969, The development of feline cell lines for the growth of feline infectious enteritis (panleukopenia) virus, J. Hyg. 67:115.

Ohshima, K., Shen, D.T., Henson, J.B., and Gorham, J.R., 1978, Comparison of lesions of Aleutian disease in mink and hypergammaglobulinemia in ferrets, Am. J. Vet. Res. 39:653.

O'Shea, J.D., and Studdert, M.J., 1978, Growth of an autonomously replicating parvovirus (feline panleukopenia): Kinetics and morphogenesis, Arch. Virol. 57:107.

Padgett, G.A., Gorham, J.R., and Henson, J.B., 1967, Epizootiologic studies of Aleutian disease. I. Transplacental transmission of the virus, J. Infect. Dis. 177:35.

Palya, V., and Kisary, J., 1978, Histopathological studies on goslings infected experimentally with the wild-type and attenuated virus of Derzsy's disease, Magy. Allatorv. Lapia 12:830.

Pan, I.C., Tsai, K.S., and Karstad, L., 1970, Glomerulonephritis in Aleutian disease of mink: Histological and immunofluorescence studies, J. Pathol. 101:119.

Parker, J.C., Cross, S.S., Collins, Jr., M.J., and Rowe, W.P., 1970a, Minute virus of mice. I. Procedures for quantitation and detection, J. Natl. Cancer Inst. 45:297.

Parker, J.C., Cross, S.S., Collins, Jr., M.J., and Rowe, W.P., 1970b, Minute virus of mice. II. Prevalence, epidemiology and occurrence as a contaminant of transplanted tumors, $J$. Natl. Cancer Inst. 45:305.

Pattison, J.R., Jones, S.E., Hodgson, J., Davis, L.R., White, J.M., Stroud, C.E., and Murtaza, L., 1981, Parvovirus infections and hypoplastic crisis in sickle-cell anaemia, Lancet 8221:664.

Paul, P.S., and Mengeling, W.L., 1980, Evaluation of a live-virus vaccine for the prevention of porcine parvovirus-induced reproductive disease in swine, Am. J. Vet. Res. 41:2007.

Paver, W.K., and Clarke, S.K.R., 1976, Comparison of human fecal and serum parvo-like viruses, J. Clin. Microbiol. 4:67.

Paver, W.K., Caul, E.O., Ashley, C.R., and Clarke, S.K.R., 1973, A small virus in human feces, Lancet 1:237.

Paver, W.K., Caul, E.O., and Clarke, S.K.R., 1974, Comparison of a $22 \mathrm{~nm}$ virus from human faeces with animal parvoviruses, J. Gen. Virol. 22:447.

Paver, W.K., Caul, E.O., and Clarke, S.K.R., 1975a, Parvovirus-like particles in human sera, Lancet 1:232.

Paver, W.K., Caul, E.O., and Clarke, S.K.R., 19.75b, Parvovirus-like particles in human faeces, Lancet 1:691.

Payne, F.E., Shellabarger, C.J., and Schmidt, R.W., 1963, A virus from mammary tissue of rats treated with X-ray or methylcholanthrene, Proc. Am. Assoc. Cancer Res. 4:51.

Payne, F.E., Beals, T.F., and Prestor, R.E., 1964, Morphology of a small DNA-virus, Virology 23:109.

Portella, O.B., 1964, Hemadsorption and related studies on the hamster-osteolytic viruses, Arch. Gesamte Virusforsch. 14:277.

Porter, D.D., 1981, Much of the increased IgG in Aleutian disease of mink is viral antibody, Proceedings 5th International Congress Virology, p. 363, Strasbourg.

Porter, D.D., and Larsen, A.E., 1968, Virus-host interactions in Aleutian disease of mink, Perspect. Virol. 6:173.

Porter, D.D., and Cho, H.J., 1980, Aleutian disease of mink: A model for persistent infection, in: Comprehensive Virology (H. Fraenkel-Conrat and R.R. Wagner, eds.), Vol. 16, Plenum Press, New York.

Porter, D.D., Dixon, F.J., and Larsen, A.E., 1965, Metabolism and function of gamma globulin in Aleutian disease of mink, J. Exp. Med. 121:889. 
Porter, D.D., Larsen, A.E., and Porter, H.G., 1969, The pathogenesis of Aleutian disease of mink. I. In vivo viral replication and the host antibody responses to viral antigen, $J$. Exp. Med. 130:575.

Porter, D.D., Larsen, A.E., and Porter, H.G., 1977a, Reduced severity of lesions in mink infected transplacentally with Aleutian disease virus, J. Immunol. 119:872.

Porter, D.D., Larsen, A.E., Cox, N.A., Porter, H.G., and Suffin, S.C., 1977b, Isolation of Aleutian disease virus of mink in cell culture, Intervirology 8:129.

Porter, D.D., Larsen, A.E., and Porter, H.G., 1980, Aleutian disease of mink, Adv. Immunol. 29:261.

Rabson, A.S., Kilham, L., and Kirschstein, R.L., 1961, Intranuclear inclusions in Rattus (Mastomys) natalensis injected with rat virus, J. Natl. Cancer. Inst. 27:1217.

Redman, D.R., Bohl, E.H., and Ferguson, L.C., 1974, Porcine parvovirus; natural and experimental infections of the porcine fetus and prevalence in mature swine, Infect. Immunity 10:718.

Reynolds, H.A., 1969, Some clinical and hematological features of virus enteritis of mink, Can. J. Comp. Med. 33:155.

Rhode, S.L., 1973, Replication process of the parvovirus H-1. I. Kinetics in a parasynchronous cell system, J. Virol. 11:856.

Rhode, S.L., 1978, Defective interfering particles of parvovirus H-1, J. Virol. 27:347.

Robey, R.E., Woodman, D.R., and Hetrick, F.M., 1968, Studies on the natural infection of rats with the Kilham rat virus, Am. J. Epidemiol. 88:139.

Robinson, G.W., Nathanson, N., and Hodous, J., 1971, Seroepidemiological study of rat virus infection in a closed laboratory colony, Am. J. Epidemiol. 94:91.

Robinson, W.F., Wilcox, G.E., Flower, R.L.P., and Smith, J., 1979a, Evidence for a parvovirus as the aetiologic agent in myocarditis of puppies, Aust. Vet. J. 55:294.

Robinson, W.F., Huxtable, C.R.R., Pass, D.A., and McHowell, J., 1979b, Clinical and electrocardiographic findings in suspected viral myocarditis of pups, Aust. Vet. J. 55:351.

Robinson, W.F., Huxtable, C.R., and Pass, D.A., 1980a, Canine parvoviral myocarditis: A morphologic description of the natural disease, Vet. Pathol. 17:282.

Robinson, W.F., Wilcox, G.E., and Flower, R.L.P., 1980b, Canine parvoviral disease: Experimental reproduction of the enteric form with a parvovirus isolated from a case of myocarditis, Vet. Pathol. 17:589.

Rohovsky, M.W., and Fowler, E.H., 1971, Lesions of experimental feline panleukopenia, $J$. Am. Vet. Med. Assoc. 158:872.

Ron, D., and Tal, J., 1981, Expanded host range and altered genomic DNA of minute virus of mice " $\mathrm{B}$ " formed in restrictive A9 cells, in: Proceedings 5th Internal Congress Virology, p. 368, Strasbourg.

Ruckerbauer, G.M., Dulac, G.C., and Boulanger, P., 1978, Demonstration of parvovirus in Canadian swine and antigenic relationships with isolates from other countries, Can. J. Comp. Med. 42:278.

Ruffalo, P.R., Margolis, G., and Kilham, L., 1966, The induction of hepatitis by prior partial hepatectomy in resistent adult rats injected with $\mathrm{H}-1$ virus, Am. J. Pathol. 49:795.

Salzman, L.A., and Jori, L.A., 1970, Characterization of the Kilham rat virus, J. Virol. 5:114.

Schettler, C.H., 1971a, Isolation of a highly pathogenic virus from geese with hepatitis, Avian Dis. 15:323.

Schettler, C.H., 1971b, Virus hepatitis of geese. II. Host range of goose hepatitis virus, Avian. Dis. 15:809.

Schettler, C.H., 1973, Virus hepatitis of geese. 3. Properties of the causal agent, Avian Pathol. 2:179.

Schofield, F.W., 1949, Virus enteritis in mink, N. Am. Vet. 30:651.

Schultz, R.D., Mendel, H., and Scott, F.W., 1976, Effect of feline panleukopenia virus infection on development of humoral and cellular immunity, Cornell Vet. 66:324.

Scott, F.W., 1980, Virucidal desinfectants and the feline viruses, Am. J. Vet. Res. 41:410.

Scott, F.W., Csiza, C.K., and Gillespie, J.H., 1970a, Feline viruses. IV. Isolation and characterization of feline virus in tissue culture and comparison of cytopathogenicity with feline picornavirus, herpesvirus, and reovirus, Cornell Vet. 60:165. 
Scott, F.W., Csiza, C.K., and Gillespie, J.H., 1970b, Feline viruses. V. Serum-neutralization test for feline panleukopenia, Cornell Vet. 60:183.

Serjeant, G.R., Topley, J.M., Mason, K., Serjeant, B.E., Pattison, J.R., Jones, S.E., and Mohamed, R., 1981, Outbreak of aplastic crises in sickle cell anemia associated with parvovirus-like agent, Lancet 8247:595.

Siegl, G., 1976, The Parvoviruses, in Virology Monographs (S. Gard and C. Hallauer, eds.), Vol. 15, Springer Verlag, Berlin.

Siegl, G., and Gautschi, M., 1973a, The multiplication of parvovirus LuIII in a synchronized culture system. I. Optimum conditions for virus replication, Arch. Gesamte Virusforsch. 40:105.

Siegl, G., and Gautschi, M., 1973b, The multiplication of parvovirus LuIII in a synchronized culture system. II. Biochemical characteristics of virus replication, Arch. Gesamte Virusforsch. 40:119.

Siegl, G., and Gautschi, M., 1978, Purification and properties of replicative-form and replicative-intermediate DNA molecules of parvovirus LuIII, in: Replication of Mammalian Parvoviruses (D.C. Ward and P. Tattersall, eds.), pp 315-325, Cold Spring Harbor Laboratory, Cold Spring Harbor, New York.

Siegl, G., and Kronauer, G., 1980, A plaque assay for feline panleukopenia virus, J. Gen. Virol. 46:211.

Siegl, G., Hallauer, C., Novak, A., and Kronauer, G., 1971, Parvoviruses as contaminants of permanent human cell lines. II. Physicochemical properties of the isolated viruses, Arch. Gesamte Virusforsch. 35:80.

Siegl, G., Hallauer, C., and Novak, A., 1972, Parvoviruses as contaminants of permanent human cell lines. IV. Multiplication of KBSH-virus in KB cells, Arch. Gesamte Virusforsch. 36:351.

Singer, I.I., 1975, Ultrastructural studies of H-1 parvovirus replication. II. Induced changes in the deoxyribonucleoprotein and ribonucleoprotein components of human NB cell nuclei, Exp. Cell Res. 95:205.

Singer, I.I., 1976, Ultrastructural studies of H-1 parvovirus replication. III. Intracellular localization of viral antigens with immuno-cytochrome C, Exp. Cell. Res. 99:346.

Singer, I.I., and Rhode, S.L., 1977a, Ultrastructural studies of H-1 parvovirus replication. IV. Crystal development and structure with the temperature-sensitive mutant $t s 1, J$. Virol. 24:343.

Singer, I.I., and Rhode, S.L., 1977b, Ultrastructural studies of H-1 parvovirus replication. V. Immunocytochemical demonstration of separate chromatin-associated and inclusionassociated antigens, J. Virol. 24:353.

Singer, I.I., and Rhode, S.L., 1978, Ultrastructural studies of H-1 parvovirus replication. VI. Simultaneous autoradiographic and immunochemical intranuclear localization of viral DNA synthesis and protein accumulation, $J$. Virol. 25:349.

Singer, I.I., and Toolan, H.W., 1975, Ultrastructural studies of H-1 parvovirus replication. I. Cytopathology produced in human NB epithelial cells and hamster embryo fibroblasts, Virology 65:40.

Soike, K.F., Iatropoulis, M., and Siegl, G., 1976, Infection of newborn and fetal hamster induced by inoculation of LuIII parvovirus, Arch. Virol. 51:235.

Spencer, H.J., 1967, Recovery of rat virus from a series of chemically induced rat leukemia, Proc. Am. Assoc. Cancer Res. 8:62.

Steiner, J.W., Perez, Z.M., and Taichman, L.B., 1966, Cell population dynamics in the liver. A review of quantitative morphological techniques applied to the study of physiological and pathological growth, Exp. Mol. Pathol. 5:146.

Storz, J., and Bates, R.C., 1973, Parvovirus infections in calves, J. Am. Vet. Med. Assoc. 163:884.

Storz, J., and Leary, J.J., 1979, Bovine parvoviruses: Epidemiology and host-virus relationships, in: Viral enteritis, INSERM, Vol. 90, pp 63-80.

Storz, J., and Warren, G.S., 1970, Effect of antimetabolites and actinomycin D on the replication of HADEN, a bovine parvovirus, Arch. Gesamte Virusforsch. 30:271. 
Storz, J., Bates, R.C., Warren, G.S., and Howard, T.H., 1972, Distribution of antibodies against bovine parvovirus 1 in cattle and other animal species, Am. J. Vet. Res. 33:269.

Storz, J., Leary, J.J., Carlson, J.H., and Bates, R.C., 1978a, Parvoviruses associated with diarrhea in calves, J. Am. Med. Assoc. 173:624.

Storz, J., Young, S., Carroll, E.J., Bates, R.C., Bowen, R.A., and Keney, D.A., 1978b, Parvovirus infection of the bovine fetus: Distribution of infection, antibody response, and agerelated susceptibility, Am. Vet. Res. 39:1099.

Syverton, J.T., Lawrence, J.S., Ackart, R.J., Adams, W.S., Ervin, D.M., Haskins, A.L., Sounders, R.H., Stringfellow, M.B., and Wetrick, R.M., 1943, The virus of infectious feline agranulocytosis. I. Characters of the virus: Pathogenicity, J. Exp. Med. 77:41.

Tabel, H., Ingram, D.G., and Fletch, S.M., 1970, Natural antibodies in sera of mink before and after the development of Aleutian disease (viral plasmocytosis), Canad. J. Comp. Med. 34:320.

Tattersall, P., 1972, Replication of the parvovirus MVM. I. Dependence of virus multiplication and plaque formation on cell growth, J. Virol. 10:586.

Tattersall, P., 1978a, Parvovirus protein structure and virion maturation, in: Replication of Mammalian Parvoviruses (D.C. Ward and P. Tattersall, eds.), pp. 53-72. Cold Spring Harbor Laboratory, Cold Spring Harbor, New York.

Tattersall, P., 1978b, Susceptibility to minute virus of mice as a function of host-cell differentiation, in: Replication of Mammalian Parvoviruses (D.C. Ward and P. Tattersall, eds.), pp 131-149, Cold Spring Harbor Laboratory, Cold Spring Harbor, New York.

Tattersall, P.J., 1981, Analysis of a sequence determining specific tissue-tropism within the genome of the minute virus of mice (MVM). in: Proceedings 5th International Congress Virology, p 369, Strasbourg.

Tattersall, P., Cawte, J., Shatkin, J., and Ward, D.C., 1976, Three structural polypeptides coded for by minute virus of mice, a parvovirus, J. Virol. 20:273.

Tattersall, P., Shatkin, A.J., and Ward, D.C., 1977, Sequence homology between the structural polypeptides of minute virus of mice, J. Mol. Biol. 111:375.

Tennant, R.W., Layman, K.R., and Hand, E.R., 1969, Effect of cell physiological state on infection by rat virus, $J$. Virol. 4:872.

Tokuhisa, S., Inaba, Y., Sato, K., Miura, Y., Akashi, H., Satoda, K., and Matumoto, M., 1981, Inhibitors of bovine parvovirus, coronavirus and rotavirus in precolostral and fetal bovine sera, Vet. Microbiol. 6:143.

Toolan, H.W., 1960, Experimental production of mongoloid hamsters, Science 131:1446.

Toolan, H.W., 1961a, A virus associated with transplantable human tumors, Bull. N.Y. Acad. Med. 37:305.

Toolan, H.W., 1961b, Studies on a viral agent associated with human tissues, Proc. Am. Assoc. Cancer Res. 3:273.

Toolan, H.W., 1964, Studies on H-viruses, Proc. Am. Assoc. Cancer Res. 5:64.

Toolan, H.W., 1965, H-1 virus in the adult hamster, Proc. Soc. Exp. Biol. Med. 119:715.

Toolan, H.W., 1966, Susceptibility of the rhesus monkey (Macaca mulatta) to H-1 virus, Nature (London) 209:833.

Toolan, H.W., 1967a, Lack of oncogenic effect of the H-viruses for hamsters, Nature (London) 214:1036.

Toolan, H.W., 1967b, Agglutination of the H-viruses with various types of red blood cells, Proc. Soc. Exp. Biol. Med. 124:144.

Toolan, H.W., 1968, The picodna viruses: H, RV, and AAV, Int. Rev. Exp. Pathol. 6:135.

Toolan, H.W., 1972, The parvoviruses, Prog. Exp. Tumor Res. 16:410.

Toolan, H.W., 1978, Maternal role in susceptibility of embryonic and newborn hamsters to H-1 parvovirus, in: Replication of Mammalian Parvoviruses (D.C. Ward and P. Tattersall, eds.), pp. 161-176, Cold Spring Harbor Laboratory, Cold Spring Harbor, New York.

Toolan, H., and Ledinko, N., 1965, Growth and cytopathogenicity of H-viruses in human and simian cell cultures, Nature (London) 208:812.

Toolan, H.W., and Ledinko, N., 1968, Inhibition by H-1 virus of the incidence of tumors produced by adenovirus 12 in hamsters, Virology 35:475. 
Toolan, H.W., Dalldorf, G., Barclay, M., Chandra, S., and Moore, A.E., 1960, An unidentified filtrable agent isolated from transplanted human tumors, Proc. Natl. Acad. Sci. USA. 46:1256.

Toolan, H.W., Buttle, G.A.H., and Kay, H.E.M., 1962, Isolation of the $\mathrm{H}-1$ and $\mathrm{H}-3$ viruses directly from human embryos, Proc. Am. Assoc. Cancer Res. 3:368.

Toolan, H.W., Saunders, E.L., Southam, C.M., Moore, A.E., and Levin, A.G., 1965, H-1 virus viremia in human, Proc. Soc. Exp. Biol. Med. 119:711.

Tratschin, J.D., McMaster, G.K., Kronauer, G., and Siegl, G., 1982, Canine parvovirus: Relationship to wild-type and vaccine strains of feline panleukopenia virus and mink enteritis virus, J. Gen. Virol. 61:33.

Trautwein, G., Schneider, P., and Ernst, E., 1974, Untersuchungen über die Pathogenese der Aleutenkrankheit. VIII. Depression der Antikörperbildung gegen Meerrettich-Peroxydase, Zentralbl. Vet. Med. Reihe B 21:467.

Urbain, A., 1933, Contribution à l'étude de la gastro-enterite infectieuse des chats, Ann. Inst. Pasteur 51:202.

Usategui-Gomez, M., 1965, A human placental fluid inhibitor to hemagglutination by H1 and H-B viruses: I. Purification, Proc. Soc. Exp. Biol. Med. 120:385.

Usategui-Gomez, M., 1968, Further purification of a human placental inhibitor to hemagglutination by $\mathrm{H}-1$ virus, Proc. Soc. Exp. Biol. Med. 127:244.

Vincent, J., 1971, Isolement en Algérie de quatre souches de parvovirus bovis, Ann. Inst. Pasteur 121:811.

Wachnik, Z., and Nowaki, J., 1962, Wirosowje zapalenie watroby u gesiat, Medicyny Weterynaryinej 6:344.

Walker, S.T., Feilen, C.P., and Sabine, M., 1980, A serological survey of canine parvovirus infection in New South Wales, Australia, Vet. Rec. 106:324.

Wills, C.G., 1952, Notes on infectious enteritis of mink and its relationship to feline enteritis, Can. J. Comp. Med. 16:419.

Woods, C.B., Pollock, R.V.H., and Carmichael, L.E., 1980, Canine parvoviral enteritis, $J$. Am. Anim. Hosp. Assoc. 16:171.

Wozniak, J., and Hetrick, F., 1969, Persistent infection of a rat nephroma cell line with Kilham rat virus, $J$. Virol. 4:313.

Wrathall, A.E., and Mengeling, W.L., 1979a, Effect of porcine parvovirus on development of fertilized pig eggs in vitro, Br. Vet. J. 135:249.

Wrathall, A.E., and Mengeling, W.L., 1979b, Effect of transferring parvovirus-infected fertilized pig eggs into seronegative gilts, Br. Vet. J. 135:255.

Zhdanov, V.M., and Merekalova, Z.J., 1962, Isolation of a virus from connective tissue of carcinogen-treated rats, Vopr. Virusol. 7:339.

Zschokke, E., 1900, Ueber coli-bacilläre Infektionen, Schweiz. Arch. Tierheilk. 42:20. 